\title{
Exploration during turbulent times: an analysis of the relation between cooperation in innovation activities and radical innovation performance during the economic crisis
}

\section{Lorena D’Agostino; Rosina Moreno}

\begin{abstract}
This paper investigates the relation between cooperation in innovation activities and innovation before and during the last economic recession. We find that cooperation in innovation activities has a stronger relation with radical innovation performance during the economic recession than before, this being true irrespectively of whether the partners are national or international. This benefit from cooperation during the economic turmoil is higher in the case of firms having different types of partners simultaneously. We also find that past cooperation in innovation activities is positively associated to innovation performance during the crisis.
\end{abstract}

\section{Introduction}

During economic recessions, firms face low demand, financial constraints, and uncertainty about future market opportunities. These conditions might induce firms to reduce their investments in innovation; as a consequence, their innovation output could be negatively affected (OECD 2009). At the same time, the economic turmoil could offer new learning opportunities (Chesbrough \& Garman 2009). Within this scenario, cooperation in innovation activities - which is one of the means the firms use to purse innovation (Tether 2002) - could either become less important for achieving innovation performance during the crisis or alternatively could offer new opportunities to cope with the challenges of the crisis. While several studies have investigated the relations 
between economic crises and R\&D expenditures (Archibugi et al. 2013a, 2013b; Cincera et al. 2012) or innovation output (Madrid-Guijarro et al. 2013), little is known about how the crisis has affected cooperation in innovation activities and its relationship with innovation performance.

The relation between business cycles and innovation is far from consensus. The countercyclical approach proposes that during recessions innovation increases as, with low demand, the opportunity costs of doing innovation is higher than in periods of growth (Aghion \& Saint-Paul 1998; Schumpeter 1939). Alternatively, the procyclical approach points out that financial constraints might prohibit the firms to maintain or increase their R\&D budget (Stiglitz 1993) and that firms postpone innovation to periods of expansions to maximize the returns (Barlevy 2004). Strategy literature has stressed the idea that learning is a crucial capacity of the firm (Kogut \& Zander 1992) and under changing external environmental firms react by adapting their learning process (Lavie \& Rosenkopf 2006; March 1991; Posen \& Levinthal 2012). In particular, in turbulent times firms might opt for an exploration strategy (e.g. more search, experimentation and risk taking) (March 1991), of which cooperation in innovation activities is a possible means (Koza \& Lewin 1998). Therefore, cooperation could offer learning opportunities even during a turbulent time such as an economic recession, and can constitute a specific strategy to face economic crises.

The empirical evidence of how the economic crisis is related to innovative investments is mostly supporting the procyclical arguments (Archibugi et al. 2013a, 2013b; Cincera et al. 2012; Laperche et al. 2011; Madrid-Guijarro et al. 2013; OECD 2009; Paunov 2012). Some of these scholars have explored the characteristics of firms that have increased their innovative investments during the crisis, showing that recessions do not hit all firms equally and that some strategies could help to face a 
turbulent climate. Among other characteristics, an explorative behaviour (e.g. searching for new market opportunities) has been found correlated to increasing innovation during the economic recession (Archibugi et al. 2013a, 2013b).

By drawing on the literature on business cycle and innovation (Aghion \& SaintPaul 1998; Barlevy 2004), and the strategy literature that has explored how firms adapt their learning processes to a changing scenario (March 1991; Posen \& Levinthal 2012), this paper explores whether cooperation in innovation activities is correlated to a better innovation performance during an economic recession. Collaboration with external partners has been recognized as an important determinant of firms' innovation performance (Becker \& Dietz 2004; Nieto \& Santamaría 2007). We expect that, when facing turbulence, an exploration strategy such as cooperating in innovation results as a successful strategy to face turbulent times by acquiring new knowledge that is far from the existing knowledge stock (March 1991; Posen \& Levinthal 2012). This can be especially true in the case of innovation that incorporates a high level of innovativeness such as radical-innovative products, for which external and diversified sources may imply knowledge that differs significantly from the one already present in the firm. Indeed, radical innovators tend to rely on the intensity of external sources, albeit in this case a too wide range of sources may be unnecessary and few key ones may be more effective (Laursen \& Salter 2006).

We use data from the Spanish Technological Innovation Panel for the period 2004-2013, which contains information on the innovative and cooperative behaviour of Spanish firms. We estimate a two-stage selection model (Wooldridge 1995). In the firststage selection equation, the dependent variable indicates whether or not the firm has invested in innovation. The second stage of the analysis estimates the relation of collaboration with innovative performance. For the purpose of our analysis, we compare 
these relations before and after the crisis. We assess not only the relation of any type of cooperation in innovation activities with performance, but we also qualify cooperation along two dimensions: geographical (i.e. exclusively-national versus international partners), and organizational (i.e. whether the firm collaborates only with one type of partners or with multiple ones). In addition, we investigate the impact of past experience in cooperation in the during-crisis years.

The paper is organised as follows. Section 2 present the theoretical framework on innovation and economic crisis, and outline some testable propositions on the relation between cooperation in innovation activities and innovation performance. The data and the model are presented in Section 3 and a descriptive analysis is provided in Section 4. Econometric results are examined in section 5. Finally, Section 6 draws some conclusions.

\section{Theoretical framework}

\subsection{Cooperation in innovation activities during economic crises}

The relation between business cycles and innovation could be countercyclical or procyclical (Aghion \& Saint-Paul 1998; Barlevy 2004; Geroski \& Walters 1995; Stiglitz 1993). The countercyclical approach relies on the Schumpterian perspective (Schumpeter 1939) that in recessions innovation increases as firms would focus more on productivity-enhancing activities, and less on production activities because demand is low. Since production and $\mathrm{R} \& \mathrm{D}$ compete for resources, decreasing growth rates could be a good moment to devote more resources to $R \& D$; hence, the incentive of carrying out innovation during recessions is higher than in periods of growing demand (Aghion \& Saint-Paul 1998). Alternatively, the procyclical approach debates that there are adverse conditions that inhibit the firms from maintaining or increasing their innovation efforts during recessions. One of the reasons is that recessions cause financial 
constraints, in terms of cash flows to devote to R\&D and access to external financing to support R\&D (Stiglitz 1993). Another reason is that since the returns from innovation have a short time span (namely, until competitors learn how to imitate the successful new products), firms postpone the investments in innovation to periods of expansions to maximize the benefits (Barlevy 2004).

Strategy literature has related changing external environments to the learning processes that firms activate in order to survive, namely an explorative or exploitative approach (Koza \& Lewin 1998; Lavie \& Rosenkopf 2006; Levinthal \& March 1993; March 1991; Posen \& Levinthal 2012). Exploration implies search, discovery, experimentation, variation, flexibility, risk taking and innovation. Exploitation implies refinement, implementation, efficiency, choice, selection and production (March 1991). A key difference between stable and turbulent environments is the relative role of explorative and exploitative learning (Levinthal \& March 1993; March 1991). When facing turbulence, an exploration strategy is necessary to adapt to a changing environment and to acquire new knowledge that is far from the existing knowledge stock (March 1991; Posen \& Levinthal 2012). This applies not without caveats. Too much focus on new knowledge may lead to too many underdeveloped ideas (March 1991), and rewards to exploration can be eroded by ongoing turbulence, as the new knowledge accumulated during the changing environments can have short-term applications (Posen \& Levinthal 2012). Although both exploration and exploitation can be performed on internal as well as on external knowledge sources, exploration activities rely more heavily on external knowledge (Rosenkopf \& Nerkar 2001). Cooperation in innovation activities are explorative in nature, while other types of alliances (marketing alliances, or supplying alliances) are exploitative (Koza \& Lewin 1998) $)^{1}$. Hence, cooperation in innovation could offer learning opportunities even during 
a turbulent time such as economic recessions, and can constitute a specific strategy to face the challenges of an economic crisis.

In particular, during economic recessions, firms could address their resources to explore new markets and technological fields (Archibugi et al. 2013a) through external collaborations (Laperche et al. 2011) and to upgrade the skills of the R\&D workforce through contacts with external specialists (Barrett et al. 2009). Since market turbulence increases the uncertainty of doing innovation, cooperation could offer a channel to increase the variety of knowledge sources (Miotti \& Sachwald 2003) and help the firms to monitor new opportunities that might arise in the near future (Archibugi et al. 2013a; Laperche et al. 2011), as focusing solely on the exploitation of existing knowledge can damage the long-term capacities of a firm "to grow beyond its core business" (Chesbrough \& Garman 2009 p. 1). Cooperation in innovation activities could also relieve the financial pressures (Cincera et al. 2012), because it allows firms to share the costs and risks of doing innovation and it may allow the firms to access to resources from partners in a better financial situation (e.g. private institutions, large corporations, or firms in fast-growing markets less affected by the recession). In these veins, Schwartz et al. (2012) find that cooperation with large firms is beneficial to innovation output in different types of subsidized R\&D agreements.

The empirical evidence of the relations of economic crises with overall innovative efforts is mostly supporting the procyclical arguments (Archibugi et al. 2013a, 2013b; Cincera et al. 2012; Filippetti \& Archibugi 2011; Laperche et al. 2011; Madrid-Guijarro et al. 2013; OECD 2009; Paunov 2012). Some of these studies detect an explorative attitude in the firms that have increased their innovative investments during the last recession. Using the UK innovation survey, Archibugi et al. (2013b) find that pursing an explorative strategy (e.g. looking at new markets) positively affects the increase in 
innovation investments during the crisis. Similarly, using a survey on 29 European countries, Archibugi et al. (2013a) shows that the small sample of firms (i.e. 9\%) that declared to have increased innovation expenditures during the crisis (which is, from the end of 2008 to early 2009) are path-breakers and have a more explorative behaviour; in particular they are: "i) smaller than before; ii) collaborating with other businesses; iii) exploring new market opportunities; iv) using methods of technological appropriation; and v) less likely to compete on costs." (p. 1259). Using the survey of companies of the EU Scoreboard about expectations on their R\&D activities, Cincera et al. (2012) find that firms with high profitability in 2008 declare their wish to increase $R \& D$ investments both before and during the crisis, which suggests that when not under financial constraints (i.e. high profitability provides cash to maintain or increase R\&D expenditure) firms increase R\&D expenditures. For Spanish SMEs, Madrid-Guijarro et al. (2013) find a strong relation between innovation and overall performance also during the crisis, suggesting that firms' commitment to innovation in turbulent times is an important driver of competitive advantage.

However, as far as our knowledge is concerned, how economic recessions influence the association between cooperation in innovation activities and innovation performance has not been studied. We expect that, despite the general level of cooperation could have decreased during the last economic recession (i.e. cooperation in innovation is pro-cyclical) as suggested by studies on overall innovation investments (Cincera et al. 2012; Filippetti \& Archibugi 2011; OECD 2009), the firms which managed to be innovative have used cooperation as an exploration strategy to cope with the crisis. Therefore, the relation between cooperation in innovation activities and innovation performance during the last economic recession would be stronger than during the expansion, suggesting that the most innovative firms during economic 
recessions are associated to technological cooperation with external partners to a larger extent than in expansion times.

In the following sections, we discuss how economic recessions may change the relation between innovation performance and various forms of cooperation in innovation activities, as investigated by recent literature. Cooperation may vary a lot in terms of purposes, duration and types of partners. In particular, existing studies have taken into account the geographical location of partners (Badillo \& Moreno 2015; van Beers \& Zand 2014; Nieto \& Santamaría 2007), the type of cooperating partners (Belderbos et al. 2004; Duysters \& Lokshin 2011), and the time-dimension of collaboration (Belderbos et al. 2015; Nieto \& Santamaría 2007).

\subsection{The geography of cooperation in innovation activities during economic crises}

During an economic downturn, focusing solely on national partners can offer an exploration strategy with relatively lower risks, as firms move outside their boundaries but within their National Systems of Innovation (NSI) (Cantwell 1989; Lundvall 1992; Porter 1990). National firms share the same problems and difficulties within a NSI, and solutions from foreign countries might not be applicable. As a consequence, national collaboration could offer the possibility to share the costs of exploring opportunities under a common changing environment.

In contrast to national cooperation in innovation, international partners offer new learning opportunities not or scarcely available nationally, which eventually boost innovation performance (Arvanitis \& Bolli 2013; Badillo \& Moreno 2015; van Beers \& Zand 2014; Berchicci et al. 2015; Frenz \& Ietto-Gillies 2009; Lavie \& Miller 2008). Having cooperation agreements with international partners provide a wide knowledge and multiple communication channels that the firms are particularly willing to use 
during a recession. Firstly, international cooperation can be a way to diversify the risk and escape the lock-in knowledge traps of own NSI, as partners reflect the technological strength and specialization of their home country NSI (Lundvall 1992). Indeed, firms that count only on their home national innovation system can be more vulnerable when a recession hits the country. Secondly, in a period of low demand, international cooperation in innovation could help to purse an exploration strategy in new or related technological fields, which are more likely to be found in foreign NSI. Thirdly, under financial constraints, firms may have better chances to share costs when the partner is international, either because the crisis hits NSI differently (some foreign countries had the resources to continue to support business R\&D, see e.g. Hud and Hussinger (2015) about Germany) or because some large players operating at the international level might be less affected from a decrease of cash flows. These arguments form the basis for our first proposition:

Proposition 1 - The relation between cooperation in innovation activities and innovation performance during the last economic recession is stronger than during the expansion, irrespectively of whether the partners are national or international.

\subsection{Cooperation in innovation activities and the different types of partners during economic recessions}

Firms collaborate with different type of actors (Miotti \& Sachwald 2003). R\&D collaborations with suppliers and clients provide vital information on technologies, markets and user's needs (Zeng et al. 2010). Horizontal cooperation is used to share the costs and risks of setting a standard technology or to comply to a new regulation (Tether 2002). R\&D collaboration with institutions usually involve low risk of knowledge leakage and it has increasingly become a crucial means to access to new scientific, basic, pre-competitive knowledge (Miotti \& Sachwald 2003), as it has increased over 
time for the incentive by governments to fund research oriented to increase competiveness of firms (Nieto \& Santamaría 2007).

Despite the fact that the choice of each type of partner depends on the strategy and resources of the firms, having multiple types of partners has been found to have a positive relation with innovation performance (Becker \& Dietz 2004; van Beers \& Zand 2014; Nieto \& Santamaría 2007). Indeed, a diversity of external sources of knowledge spurs synergies and novel associations and exposes the firm to skills and expertise from different technological fields (Chesbrough 2003; Cohen \& Levinthal 1990; Laursen \& Salter 2006). Eventually, the firm relying on multiple types of cooperation partners increases its capacities to create innovative products.

In time of economic turmoil, firms might avoid having a broad network of partners, since too much openness could become costly and inefficient for the firm (Laursen \& Salter 2006). Indeed, it has been observed that firms which innovate mainly through collaboration with others tend to have fewer variety of partners (Barge-Gil 2010), as some benefits arise from focusing on a single type of partners, such as the development of certain routines that facilitate knowledge exchange (Belderbos et al. 2015). However, the benefits of relying on a variety of sources could be higher than the ones from having a single type of partners, especially during a crisis because a higher diversity of external knowledge increases the chances to find channels allowing firms to broaden the pool of technological opportunities. This way, in an economic crisis, using a wide range of external actors allows the firm to have a broader spectrum of experiences with diverse partners that in some instances can be living the crisis differently, allowing for wider knowledge than collaboration with only one type of partner. Hence, the diversity in the type of partners is associated to innovation performance more intensively during economic crises. 
In addition, if these partners are international, the combination of organizational and geographical diversity should reinforce the relations with innovation performance. In this case, not only firms benefit from specialized knowledge coming from different types of partners, but they are also able to access to different knowledge bases in foreign NSI, as discussed in Section 2.2. From this reasoning, it follows the next proposition:

Proposition 2 - The relation between cooperation in innovation activities with different types of partners and innovation performance during the last economic recession is stronger than during the expansion.

2.4 The importance of time: continuity and persistence in cooperation in innovation activities

Previous experience in technological cooperation might help the firms in different ways (Belderbos et al. 2015; Nieto \& Santamaría 2007; Rothaermel \& Deeds 2006). Firstly, as a firm's current innovation capabilities are determined by its history and experience, having participated in technological collaborations determine current innovation capabilities (Nieto \& Santamaría 2007). Secondly, previous experience in cooperation provides the firms with the necessary managerial capabilities to deal with alliances (Rothaermel \& Deeds 2006), as well as to build up reputation and trust among partners (Nieto \& Santamaría 2007). Thirdly, repeated and extended collaborations might provide the necessary incubation time before new collaborations start to have an effect on firm's innovation performance (Belderbos et al. 2015).

If the repeated collaboration regards the same partner, reputation and trust between partners could offer a channel to access more quickly or more effectively to knowledge on markets. Then, if the repeated collaboration regards the same type of partners (e.g. suppliers, clients, competitors, institutions), firms could have developed some mutual routines and capabilities to deal with problems, which during an economic turmoil can constitute an advantage towards firms that have not a history of accessing to 
external sources of knowledge. Based on the above-mentioned arguments, we put forward the following proposition:

Proposition 3 - Experience in past cooperation is positively associated to innovation performance during the last economic recession.

The literature on the patterns of the previous experience in $R \& D$ collaboration has highlighted that the quantity of collaboration done in the past is only a part of the story. Indeed, high levels of alliance activity have diminishing returns (Rothaermel \& Deeds 2006; Sampson 2005). One possible explanation for this is that only the most recent experience offers lessons, especially under changing external environments (Samson 2005). In addition to that, Belderbos et al. (2015) find that it is mostly persistent and recent collaborations (i.e. in two previous consecutive years) which are important for innovation performance.

Although the most recent experience offers the most valuable knowledge, the firms that have pursued an explorative behaviour under different business climates could benefit of a variety of knowledge. Indeed, as the external knowledge acquired during a certain period becomes part of the current knowledge stock of firms, the combination of past external knowledge and current external knowledge could boost new innovative ideas (Kogut \& Zander 1992). Accordingly, firms which have cooperated both before and during the crisis may have higher innovative performance than firms that have cooperative agreements only before or only during the crisis. All of these arguments lead us to posit these propositions:

Proposition $4 a$ - The most recent experience in cooperation is positively associated to innovation performance during the last economic recession.

Proposition $4 b$ - The most remote experience in cooperation is negatively associated to innovation performance during the last economic recession. 
Proposition $4 c$ - The combination of the most recent and the most remote experience in cooperation is positively associated to innovation performance during the last economic recession more strongly than the most recent only and the most remote only cooperation.

\section{Data and the model}

\subsection{Data}

Our empirical analysis uses data from the Spanish Technological Innovation Panel (PITEC) $^{2}$ from 2004 to 2013. The survey is carried out by the Spanish National Statistics Institute (INE), the Spanish Foundation for Science and Technology (FECYT), and the Foundation for Technical Innovation (COTEC). Participation in PITEC survey is mandatory by law which ensures a large and consistent sample size and a high response rate; however, some firms are not observed for the entire period given the partially random sampling for small enterprises (Belderbos et al. 2015). The survey follows the Oslo Manual methodology applied in the Community Innovation Survey with respect to the selection of variables and indicators (OECD 2005).

The unit of analysis is the enterprise (firms, from now on), which may belong to larger corporate groups. Our initial unbalanced sample includes a panel of 85755 observations, which represents 10917 manufacturing and service firms with at least ten employees and positive sales, and which did not report any significant event that would impact employment. This sample constitutes $85 \%$ of total firms surveyed in 2004-2013 in PITEC. Since this sample decreases over time because some firms may report a major issue ${ }^{3}$, we test our predictions on a balanced panel of firms that are present during the whole period $2005-2013^{4}$. This balanced panel comprises 53595 observations, i.e. 5955 firms per 9 years. 


\subsection{The model}

We follow a two-stage approach to address the potential selection bias on the estimation of the innovation performance equation. The first stage consists of a binary selection model using all sample observations and considering as dependent variable whether the firm has carried out innovation activities ${ }^{5}$ and 0 otherwise $(d)$. The second stage consists in the estimation of the innovation performance equation, the dependent variable being innovative performance $(y)$, taking explicit account of the selection process.

The specification of the model is as follows:

$$
\begin{aligned}
& d_{i t}=1\left[z_{i t} \gamma+\eta_{i}+u_{i t}>0\right] \\
& y_{i t}= \begin{cases}x_{i} \beta+a_{i}+s_{i t} & \text { if } d_{i t}=1 \\
0 & \text { if } d_{i t}=0\end{cases}
\end{aligned}
$$

with $i=1, \ldots, \mathrm{N}, t=1, \ldots, \mathrm{T}$, and $1[$.$] an indicator function that takes on the value 1$ if the expression between square brackets is true and 0 otherwise; $\gamma$ and $\beta$ are unknown parameter vectors to be estimated and $z_{i t}$ and $x_{i t}$ are vectors of explanatory variables with possibly common elements. Valid exclusion restrictions are assumed in equation (2). $\eta_{i}$ and $\alpha_{i}$ are unobserved individual specific effects which may be correlated with $z_{i t}$ and $x_{i t}$, respectively; and $u_{i t}$ and $\varepsilon_{i t}$ are the idiosyncratic errors. The innovation performance variable $\left(y_{i t}\right)$ is only observable if the firm made an innovative investment $\left(d_{i t}=1\right)$ and the parameter vector of interest to estimate is $\beta$.

We use the Wooldridge's (1995) consistent estimator for panel data with sample selection. First, we consistently estimate $\beta$ by estimating a probit of $d_{i}$ on $z_{i}$ for each $t$ 
and then saving the inverse Mills ratio, $\tilde{A}_{i r}$. Second, the method estimates by pooled OLS the equation of interest augmented by the inverse Mills ratio and the means of the time-varying explanatory variables $\left(x_{i}\right)$ using the selected sample. ${ }^{6}$ The resulting equation is (Wooldridge 2010):

$y_{i t}=x_{i t} \beta+x_{i} \psi+\sum_{t=1}^{T} \rho_{t} D_{t} \hat{\lambda}_{i t}+e_{i t}$ for all $d_{i t}=1$

where $D_{t}$ is a time indicator variable.

In order to compare the cooperation behaviour before and during the crisis, we firstly estimate Eq. (3) for the whole period, with 1-year lag of time-variant regressors, both for the unbalanced $(t=2004, \ldots, 2013)$ and balanced panels $(t=2005, \ldots, 2013)$. Secondly, we run Eq. (3) for the pre-crisis years $(t=2005, \ldots, 2010)$, and for the during-crisis years $(t=2011, \ldots, 2013)$ for the balanced panel to ensure comparability. These time frames build on the fact that the real economy was hit by the crisis in 2009 (European Commission 2015; Hud \& Hussinger 2015; Keeley \& Love 2010) and that our cooperation variables refers to cooperation behaviour in the survey year $t$ and in the previous two years. ${ }^{7}$ Hence, estimating the dependent variable in 2011 on 1-year lag cooperation means that we are considering cooperation behaviour in 2010, 2009, and 2008, meaning that in the "during crisis" estimation we allow for cooperation only in one possible year of overlapping with the pre-crisis period (i.e. 2008). Accordingly, estimating the dependent variable in 2010 on 1-year lag cooperation means that we are considering cooperation behaviour in 2009,2008 , and 2007 , meaning that in the "precrisis" estimation, we allow for cooperation only in one possible year of overlapping with the during-crisis period (i.e. 2009). There is no other overlapping in the rest of the years under consideration. 


\subsubsection{The endogeneity issue}

The relation between cooperation and innovation performance raises an issue of endogeneity in two possible ways, i.e. simultaneity or reverse causality, and omitted variables. Indeed, past innovation performance may affect the likelihood to cooperate in the future (Frenz and Ietto-Gillies 2009), as innovators are more capable or more willing to cooperate. We partly account for simultaneity by using 1-year lag on the cooperation variable, although we are aware that the high persistence of these variables prevents us from solving the problem completely. With regards to omitted variables, we can imagine a set of unobserved characteristics correlated to innovation and cooperation (e.g. managerial capacity, cooperative attitude, availability of valuable partners) for which we cannot control. One way to address endogeneity is by instrumenting cooperation. A good instrument would affect innovation performance through cooperation only, and should have enough explanatory power in predicting changes in cooperation. However, with an innovation survey like PITEC, such instrument is particularly difficult to find since all variables are somewhat correlated to innovation and, being innovation persistent over time (Raymond et al. 2010), a problem of inverse causality or simultaneity is always possible. Hence, endogeneity warns us about the inaccuracy of interpreting the results of our estimation as a causal effect of cooperation on innovation performance. Instead, our results are the signal of a relation between the two variables while controlling for selection bias and a set of firm-level characteristics.

\subsubsection{Dependent variables}

In the first stage, the dependent variable is a binary indicator, equal to 1 if the firm has been engaged in any innovation activity in $t$. In the second stage, the dependent variable is innovation performance, defined as the share of sales in $t$ due to new or significantly improved products that constitute a novelty for the firm (new incrementally-innovative products) or to the market (new radically-innovative 
products), introduced in the survey year or in the previous two years. New-to-themarket products can be seen as more "radical" innovation since they push the technological frontier in the industry (Belderbos et al. 2015). We transform these shares as the ratio between the ratio of new sales on total sales and the complement to 1 of this latter ratio, and then transformed in logarithm. This measure has the advantage of being closer to a normal distribution and being symmetric (Barge-Gil 2013; Raymond et al. 2010; Robin \& Schubert 2013).

\subsubsection{Explanatory variables}

In the first stage, building on an established literature on the determinants of innovation, we control for firm size (size) and we also introduce its squared term (size 2) to take into account nonlinearities (Robin \& Schubert 2013); in addition, we insert the market share of the firm and whether the firm belongs to a group (Raymond et al. 2010; Vega-Jurado et al. 2009; Veugelers \& Cassiman 1999). We also introduce barriers to innovation by means of four Likert-type variables: cost obstacles, knowledge obstacles, market obstacles, and other obstacles. We allow a time lag of one year for all explanatory variables. The variables group, and the four variables related to the obstacles to innovation are considered as exclusion restrictions for the second stage, meaning that they are likely to be associated to the decision to carry out innovation activities, but are weakly correlated to innovation performance. Finally, industry dummies are introduced at 2-digits CNAE-2009 classification.

In the second stage, the key explanatory variable is cooperation, which takes the value 1 if the firm declares to have undertook innovative activities with other enterprises or entities (external or from the same-group) in the survey year and the two previous years ${ }^{8}$. Cooperation in innovation activities may vary a lot in terms of duration. In order to be successful, cooperation requires time to build trust among partners (which 
is effective to transfer knowledge) and to accumulate valuable knowledge. At the same time, the relation between cooperation and innovation might have diminishing marginal returns, as after a certain point of time the disadvantages (such as unintended knowledge spillovers and managerial complexities) take over the benefits (Du et al. 2012). In general, alliances last more than a year and empirical works assume a time window between two and five years (Tomasello et al. 2015; Rosenkopf and Schlling, 2007; Stuart 2000). Unfortunately, CIS data do not provide information on the duration of cooperation in innovation activities. We qualify cooperation along two dimensions, geographical (i.e. the home-country of the partner) and organizational (i.e. the type of partner). We construct the variable national only, which is equal to 1 if the firm declares to have collaborated only with national partners, 0 otherwise; in addition, we build the variable international, which is equal to 1 if the firm declares to have collaborated at least with an international partner.

By using the information on the type of partners, we identify three typologies: vertical (i.e. suppliers and clients), horizontal (i.e. with competitors or other firms in the same branch of activity), and institutional (i.e. university, private and public research centres, institutes, laboratories, consultants, or technological centres). We firstly identify the firms that cooperate exclusively with firms that belong to the same group and are in the same country (national only+same group only). Then, we identify the firms that were collaborating only with a type of national partner not from the same corporate group (henceforth, external) ${ }^{9}$ : national only+vertical only, national only+horizontal only, and national only+institutional only. In addition, we introduce national only+multipartners, which takes the value 1 if the firm is cooperating with at least two different types of national external partners. As far as the international collaboration is concerned, we firstly identify the firms that cooperate exclusively with 
firms in the same group in foreign countries and, if it is the case, also nationally (international+same group only). Then, we build a set of variables controlling for whether the firms were collaborating only with one type of external partner internationally and, if it is the case, also nationally: international+vertical only, international+horizontal only, and international+institutional only. In addition, we introduce the variable international+multipartners, which is equal to 1 if the firm is collaborating with at least two different external partners, at least one of which is located abroad. Finally, although we are not interested in isolating the effects of cooperating with firms in the same group, we introduce a control that accounts for those firms that collaborate only with firms from the same group (internationally, and/or nationally) (same group only) ${ }^{10}$.

As long as the intertemporal dimension is concerned, we construct the variable continuity which counts the number of years of cooperative behaviour up to $t-1$ (Nieto \& Santamaría 2007). We also create three dummy variables, indicating whether the firm declares cooperation in innovation activities in $t-1$ and before the crisis (in 2005-2008) (persistent cooperation), only during but not before (during crisis cooperation), and only before the crisis (before crisis cooperation). ${ }^{11}$

For the second-stage step, additional controls are size, its square term and market share (Raymond et al. 2010; Vega-Jurado et al. 2009; Veugelers \& Cassiman 1999). In addition, we introduce the share of internal R\&D expenditures over total sales (in-house $R \& D$ intensity) as a proxy for a firm's absorptive capacity (Becker \& Dietz 2004), foreign ownership (Nieto \& Santamaría 2010), whether the firm conducted internal R\&D activities continuously (permanent $R \& D$ ) (Raymond et al. 2010), the degree of openness (D'Este et al. 2015; Laursen \& Salter 2006), the importance of demand-pull factors (Raymond et al. 2010), the international market scope as declared by firms 
(Cassiman \& Veugelers 2006; Nieto \& Santamaría 2007), and whether it was a new firm in 2004 or in 2005 (Archibugi et al. 2013b). A set of 2-digit industry dummies is introduced.

The control variables are measured on annual base, with the exception of openness, demand-pull, international market, and new firm which instead refer to the year of the survey $t$ and the two previous years. The appendix provides more details on the definitions of the variables (Table A1) and the correlation matrix of the variables used in the second-stage equation (Table A2).

\section{Descriptive analysis}

What began as a financial crisis quickly morphed into a crisis in the real economy in late 2008, when many countries around the world started to slump into recession (Keeley \& Love 2010). Similarly to Hud and Hussinger (Hud \& Hussinger 2015) for Germany, we consider 2009 as the year of the beginning of the crisis, since 2009 is the first year with negative GDP growth in Spain, which returns to positive in 2014 (European Commission 2015).

Table 1 provides an overview on the cooperation and innovation behaviour of firms in selected years. The total sample of firms based on our selection decreases over years. It ranges from 8438 firms in 2004 to 7510 in 2012, with a peak of 9705 in 2006. The number of innovative firms (i.e. which have product or/and process, and/or ongoing innovation) and cooperative innovative firms follow this trend. However, if we consider

the shares of these two groups of firms, some differences emerge. The share of innovative firms on total sample firms is higher before the crisis than after. In 2008, the innovative firms were 6925 (i.e. $76.07 \%$ of total sample firms); in 2010 they were 6344 and in 2012 they dropped to 4991, which account respectively for $76.78 \%$ and $66.46 \%$ of total sample firms. Instead, for the cooperative innovative firms, after a decreasing 
trend up to 2008 (i.e. from $37.77 \%$ in 2004 to $34.89 \%$ in 2008), this share increases during the crisis, up to $41.68 \%$ in 2012 . Hence, despite both the absolute number of innovative and cooperative innovative firms, following the general pattern, have declined during the crisis, the ratio of cooperative innovators has actually increased, which signals that cooperative innovative firms have decreased at a slower pace than innovative.

\section{[TABLE 1 ABOUT HERE]}

Table 2 shows the number and share over total cooperative innovative firms by geography and type of partners in selected years. The share of firms that cooperate only with national partners decreased since 2006 in favour of firms doing only or also international agreements. However, exclusive national cooperation constitutes the majority (i.e. $61.79 \%$ in 2004 and $59.42 \%$ in 2012), while having at least an international partner account for $32.21 \%$ in 2004 and $40.58 \%$ in 2012 . We observe an internationalization process in the cooperation agreements carried out by Spanish firms.

The distribution of firms across types of partners reflects that roughly half of firms have multi-partner strategies and that this trend is increasing. Firms seem to look for diverse knowledge that can be achieved thanks to cooperation with a variety of types of partnerships. In terms of share, it goes from $43.21 \%$ in 2004 to $50.29 \%$ in 2012 . Among single-partner firms, firms collaborating only with institutions exhibit the highest percentage, with a decreasing trend during the crisis, from $29.45 \%$ in 2004 to $20.72 \%$ in 2012 . Firms collaborating only with vertical partners are the second largest group, which shows a quite stable trend, from $17.09 \%$ in 2004 to $17.26 \%$ in 2012 , except for a peak of $20.46 \%$ in 2006. As third largest group, we find the firms collaborating with same-group firms, with an increasing trend. Finally, collaboration with competitors is the least frequent, and with a decreasing trend. 
By looking at the distribution across geography and partners, the patterns of firms collaborating exclusively with one type of partners are reproduced also at national and international level. Similarly, the multi-partner categories are among the largest group. Interestingly, in 2004 firms collaborating exclusively with national institutions or research centres were $24.93 \%$, but it dropped to $18.94 \%$ in 2012 (i.e. the third largest category). These figures show that cooperative innovative firms purse a diversified strategy, both at national and international level, which has been reinforced during the crisis. Conversely, exclusive institutional alliances at the national level (which is a peculiar trait of Spanish NSI) (Belderbos et al. 2015) seems to lose ground during the crisis, probably for the reduction of public funding for incentivizing firms to maintain cooperation agreements with university and research centres.

\section{[TABLE 2 ABOUT HERE]}

In Table 3, we use the balanced panel and compare the innovation performance for innovative, cooperative innovative and non-cooperative innovative firms in three different time frames (whole period, pre-crisis period, and during-crisis period) ${ }^{12}$, and with three different measures of innovation performance: the share of sales from new products, the share of sales from products new only to the firm (a proxy for products that incorporate an incremental innovation), and the share of sales from products new to the market (proxying for products incorporating a breakthrough innovation). Cooperative innovative firms have a higher innovation performance than noncooperative innovative firms, and this holds true both across time frames and across different measures of innovation performance. The share of sales from new products has decreased during the crisis for all categories of firms suggesting that on average the crisis has affected innovation outputs of all firms. However, it seems that the share of sales from products incorporating a radical innovation was hit by the crisis to a lesser 
extent; indeed, the overall mean of the innovation performance of cooperative firms in the pre-crisis is $13.12 \%$ while during the crisis is $12.59 \%$, namely about 0.5 points of change, the lowest variation across the different categories of firms and measures of innovation performances between pre- and during-crisis figures.

\section{[TABLE 3 ABOUT HERE]}

Table 4 shows the innovation performance of cooperative firms which had cooperation in innovation activities for the first time during the crisis, and cooperative firms which undertook cooperation only before the crisis ${ }^{13}$, for the balanced panel. The figures are shown in the three time frames, and with three different measures of innovation performance, similarly than in Table 3 . The overall mean of innovation performance is systematically lower during the crisis than before for both categories of firms and for the three measures of innovation performance. The decrease is less prominent for first-time cooperative firms in the crisis, suggesting that the most recent cooperation behaviour during the turbulent time is more important than remote cooperation in expansion periods, and more strongly in the case of producing new radical-innovative products.

\section{[TABLE 4 ABOUT HERE]}

\section{Econometric results}

We firstly estimate the selection equation (the propensity to invest in innovation) for each year. Table A3 in the Appendix presents the results. From these estimations, we obtain the inverse Mill's ratio which are subsequently included in the second stage. Inverse Mill's ratios account for the selection bias caused by the fact that we only observe the innovation performance of firms that made an innovation investment.

Table 5 shows the estimation results of the second-stage model. For the whole period, we estimate the unbalanced panel where the dependent variable is the share of 
sales from new incremental-innovative products (model 1) and new radical-innovative products (model 2). The variable of interest cooperation is negative and non-significant for incremental innovation, while it is positive and statistically significant $(p<0.01)$ for the radical innovation performance (model 2). In line with previous studies suggesting that technological cooperation has a more important impact on highly innovative products (Nieto \& Santamaría 2007), we find that external collaboration in innovation is positively associated to the share of sales due to products new to the market, while such innovation strategy is negligible for the shares of sales due to products new to the firm. A possible reason for these different results is that in order to outweigh the costs of accessing to external knowledge not available inside the firms or through other means, such as knowledge spillovers or purchase of $R \& D$ services, the firms may use cooperation while aiming at breakthrough innovation. Accordingly, other sources of knowledge may be relevant when the firms is in the process of boosting the innovation sales of new incremental-innovative products. This empirical result is also in line with the idea that cooperation in innovation is an explorative strategy that has more to do with discovering and risk-taking while searching for some long-term returns (more likely in the case of radical innovation), and less to do with the mere reception of innovative products already present in the market which, although correlated to innovation sales for those products, are not necessarily searched within an explorative strategy. For these reasons, we restrict our subsequent empirical analyses to the share of sales from new radical-innovative products.

Model 3 in Table 5 shows the balanced panel for radical innovation performance. For the pre-crisis years and the during-crisis years, we run only the balanced panel (model 4 and 5, respectively) in order to have the same firms before and after the crisis, and therefore ensure comparability between the two estimations. Cooperation is 
positive and significant at $p<0.01$ in all three specifications of the balanced panel. For the whole period, the coefficient is slightly higher for the unbalanced panel (model 2) than the balanced one (model 3). All the remaining controls, when significant, show the expected sign in the unbalanced panel. Size, size 2, openness and new firm loses its significance in the balanced panel. In-house $R \& D$ intensity is positively correlated to innovation performance (Belderbos et al. 2015; Nieto \& Santamaría 2007). Size is negative and its squared term is positive, thus suggesting a non-linear relation between size and performance (Badillo \& Moreno 2015; Cassiman \& Veugelers 2006). In both model 2 and 3, firms that have carried out $R \& D$ continuously (permanent $R \& D$ ) have better performance, as they have accumulated knowledge and implemented learning processes (Badillo \& Moreno 2015). In line with previous studies, the degree of openness of the firm and the demand-pull control are positively correlated to innovation performance (Belderbos et al. 2015; Duysters \& Lokshin 2011), although openness loses its significance in the balanced panel, suggesting that survival innovative firms do not necessarily use a large spectrum of knowledge sources. The fact that the firm has been newly established at the beginning of the period under consideration is positively associated to innovation sales, but this control is negative and not significant in the balanced panel, suggesting that survival innovative firms are long-established organizations.

In models 4 and 5 we observe that during the crisis the cooperation coefficient is about five times larger than in the pre-crisis years. We run a test of comparison of the cooperation coefficients for the balanced panel across the two time frames, and, as reported in the last row in Table 5, the test rejects the null hypothesis of equality at $p<$ 0.01. Hence, having cooperation agreements is positively related to the innovation performance of Spanish firms during the crisis to a greater extent than before the crisis, 
suggesting that an explorative strategy is associated to the flows of knowledge not available inside the firms in those high innovation performers that aim at radicalinnovative products during turbulent times.

\section{[TABLE 5 ABOUT HERE]}

We now turn to explore the different impacts of cooperation before and during the crisis according to the geographical locations of the partners. Table 6 shows the estimations for the whole period with both the unbalanced (model 6) and the balanced panels (model 7), and for the latter in the pre-crisis (model 8) and the during-crisis years (model 9). In line with previous studies (Badillo \& Moreno 2015), both national only and international are positive and significant at $p<0.01$ in the whole-period models. When we focus on the difference between the two periods, national only cooperation is unimportant before the crisis (the coefficient is small and non-significant), while it turns significant and larger during the crisis. Instead, the coefficient of international cooperation is significant both before and during the crisis, and larger during the crisis. The comparison tests reported in the bottom row in Table 6 show that these differences across periods are statistically significant for both types of cooperation (at $p<0.01$ ). These results suggest that during the crisis those firms that implemented an exploratory strategy in any geographical direction increase their innovative outcomes, in line with our proposition 1. While national cooperation is not associated to higher performance before the crisis, during the crisis such exploratory strategy - even if confined to national borders - becomes significantly correlated to innovation performance. However, by looking at the coefficients of national only and international during the crisis (model 9), we can see that the relation between collaborating with foreign partners and innovation is higher, as the coefficient of international alliances is almost double the size of exclusively national cooperation. 


\section{[TABLE 6 ABOUT HERE]}

We report the estimates on the relation of cooperation by geography and type of partners in Table 7, for the whole period with both the unbalanced and balanced panels (models 10 and 11, respectively), and for the pre-crisis and the during-crisis years (models 12 and 13) for the balanced panel. As far as the before- and during-crisis periods are concerned (models 12-13), the only cooperation coefficients that are positive and significant in both periods are the ones related to multiple partners (i.e. national only+multi-partners, and international+multi-partners), which are systematically higher during the crisis than before. Others become significant during the crisis, and they are related to institutional and vertical partners at both levels (i.e. national only+vertical only, national only+institutional only, international+vertical only, and international+institutional only).

The bottom rows in Table 7 show the tests of equality of the cooperation parameters in both periods, suggesting that all the above-mentioned coefficients in the during-crisis years are statistically significantly higher than before the crisis. In particular, the tests for the multi-partner variables reject the null hypothesis of the equality of coefficients before and during the crisis, both at the national and international level at the highest threshold of significance, i.e. $p<0.01$. This suggests that relying on multiple types of sources is associated to higher innovation performance. The coefficient of international multi-partners is higher than the one for national during the crisis, suggesting that in the former case firms pursuing a combination of organizational and geographical diversity tend to be related to higher performance. These results confirm the expectation of proposition 2 .

The coefficient of national only+institutional only, which is positive and statistically significant during the crisis $(p<0.05)$ and not before, is significant in the 
comparison test $(p<0.05)$. Similarly, the test of the coefficient of international+institutional only is statically significant $(p<0.05)$, and in the estimates the coefficient is positive and significant at $p<0.05$ only during the crisis. These results suggest that the firms which successfully managed to access to institutional partners are better innovation performer, even though this was the only type of partners, either nationally or internationally (Arranz et al. 2008). During the crisis, the coefficient of international institutional cooperation is higher than the national one, confirming the value added of foreign partners.

Both national only+vertical only and international+vertical only are positive and significant only in the during-crisis estimations, the coefficient of the latter being larger than the former. For these parameters, the test detects a statistically significant difference in the two periods $(p<0.05)$. These results about vertical partners point out that value-chain connections (i.e. clients and suppliers) are particularly important sources of knowledge during the crisis, even if it is the only cooperation, although international linkages are more strongly associated to performance. Finally, for horizontal cooperation, for which the coefficients are not significant, the comparison tests do not suggest any significant change during the crisis.

\section{[TABLE 7 ABOUT HERE]}

Finally, we estimate how past experience in cooperation in innovation activities is related to firms during the crisis. Table 8 shows the estimations for the balanced panel during the crisis, in which we introduced a variable for continuity in cooperation (continuity) that accounts for the total years of collaboration in innovation activities up to $t-1$ (model 14). The coefficient is positive and significant at $p<0.01$, suggesting that cumulative past experience is associated to the current innovation performance of firms during the crisis (Nieto \& Santamaría 2007), confirming our proposition 3. To explicitly 
test whether the most recent cooperation matters more than remote alliances, and how the combination of cooperative behaviour under different business climates is related to innovation performance during recession, model 15 in Table 8 shows the estimation in which we introduced three dummy variables accounting for whether the firm has collaborated only in t-1 (during-crisis cooperation), or only before 2008 (before-crisis cooperation), or both in $t-1$ and before 2008 (persistent cooperation). Results show that newly-cooperative firms in the recession perform well (coefficient is positive and significant at $p<0.01$ ) (confirming proposition $4 \mathrm{a}$ ), while experience in the expansion period does not have a statistically significant relation with innovation performance during the crisis (confirming proposition 4b), which reinforces the idea that what matters is the most recent cooperation behaviour. However, a combination of past experience in the current business climate and in the previous expansion period (persistent cooperation) exhibits a higher coefficient than that of the during-crisis cooperation, which signals that the combination of past acquired knowledge and current external knowledge is positively associated to innovation performance during recessions (confirming proposition 4c). Indeed, the recent experience offers the most valuable knowledge, but the firms that have followed an explorative strategy under different business climates are better performers. The external knowledge acquired during a certain period becomes part of the current knowledge stock of firms, hence high innovation performers are more likely to find a combination of past and current external knowledge that inspires new innovative ideas (Kogut \& Zander 1992) than cooperative agreements undertaken only before or only during the crisis.

[TABLE 8 ABOUT HERE] 


\section{Conclusions}

During the recent economic recession, firms have been less willing to invest in innovation. Innovation collaboration has followed a similar pattern, as the absolute number of cooperating firms has decreased during the crisis. However, since a group of firms managed to conduct innovation alliances during the crisis, in this study, we have investigated how the last economic recession shaped the role of cooperation in innovation activities on innovation performance.

Our findings point out that cooperation in innovation activities has been successfully associated to innovation performance during the last recession, as part of an exploratory strategy aimed at accessing knowledge not available inside the firms and increasing diversity of knowledge sources (March 1991). These positive relations are higher during the crisis than before every time the cooperation involves an increased diversity of knowledge sources (national vs international cooperation, with multiple partners, and under different business climates). Also, cooperation turns important in cases which were irrelevant before the crisis (i.e. national only, or vertical and institutional at both national and international levels), reinforcing the idea that a cooperation behaviour is among the characteristics that help the firms to deal with economic turbulence.

In particular, as far as the geographical dimension is concerned, we find that the positive relation with innovation performance is stronger during the crisis than before in both cases analysed, that is when firms cooperate with national partners only and when they are from abroad. Exclusively national cooperation was an unimportant factor before the crisis and its increased relevance during an economic turmoil points out that during a crisis firms are searching for external knowledge in any direction, irrespectively of the geographical locations (proposition 1). Indeed, not all firms are 
equipped to undertake international alliances but the ones that explore within national borders have higher innovation performance than firms non-cooperating. In line with previous studies, in any period considered, international cooperation in innovation activities is more strongly correlated to performance than national, as international partners are associated to the access to heterogeneous sources of knowledge and to frontier-technological inputs (Berchicci et al. 2015).

Regarding the organizational dimension, we find that when the firm cooperates with a variety of partners (organizational diversity), there is outstanding evidence of a stronger relation with innovation performance during the crisis than before. Both before and during the crisis, this relation is at the maximum when the variety of partners includes at least an international tie (proposition 2). In addition, we find that some types of cooperation have become important elements in better innovation performers during the crisis, while they were unimportant before. This is the case of cooperating only with vertical or institutional partners, either nationally or internationally. This result reinforces the importance of research organizations to support firms (Schwartz et al. 2012), especially during turbulent times, even if it is the only type of cooperation. However, also in this case, during the crisis the presence of an international tie is associated to higher innovation sales. Similarly, vertical cooperation fails to be crucial before the crisis and becomes higher during the crisis, suggesting that this exploration strategy in any direction is pursued by the best innovation performers, even if it is the only type. Also in this case, during the crisis the coefficient of international vertical ties is higher than national ones. Finally, horizontal cooperation does not have a significant relation with innovation performance.

Finally, we explore the role of past experiences in innovation agreements (Belderbos et al. 2015; Nieto \& Santamaría 2007) in the innovation performance during 
the crisis and we find that continuity in cooperation in innovation activities has a positive impact (proposition 3). We also find that more recent innovation collaboration during the crisis has a positive relation (proposition 4a), while remote alliances before the crisis are unimportant (proposition 4b). However, if firms have experience in both business climates, then the combinative capabilities resulting from these technological collaborations have the strongest relation to innovation performance (proposition 4c), suggesting that also inter-temporal knowledge diversity is an important element during the crisis.

Our findings provide useful managerial implications. When facing the challenges of a crisis, an exploration strategy such as collaboration in innovation activities might help the firm to maintain a certain degree of innovation by increasing the sources and variety of knowledge. Technological and market turbulence causes ideas and products to go obsolete very quickly (Hung \& Chou 2013), and during a crisis the combinations of new external and existing internal knowledge amplify the opportunities to create new successful products and boost innovation sales. Managers should search for these opportunities in international collaborations and with a variety of national or international partners, not only because multi-partner collaborations have the highest impact on innovation performance in general, but also because they turn to be more important during an economic turmoil. In some cases, firms may not have the capabilities or resources to have a large spectrum of collaborations, and our findings suggest that during the crisis even the types of collaborations whose importance is negligible during expansions could be associated to innovation sales during crises. Hence, managers should consider applying an exploration strategy in any direction, being aware than international and multi-partner cooperation are related to the highest innovative performance. 
We believe that our findings bear some suggestions for policy-makers. Especially during the last economic crisis which started as a financial crisis and had repercussions on the sovereignty debts, many governments undertook dramatic cuts on R\&D budgets, like in Spain (Cruz-Castro \& Sanz-Menéndez 2015). Other countries, under less stringent financial pressure, have implemented policies to support private R\&D investments, such as the $\mathrm{R} \& \mathrm{D}$ subsidies provided by the German government to compensate the reduction of private R\&D (Hud \& Hussinger 2015). Our study suggests that cooperation in innovation activities during a crisis should be promoted by governments. In contrast to other R\&D public support (subsidies, direct R\&D funding), policies in favour of innovation collaboration could be designed even under a lack of public financial resources. They can take the forms of tax exemptions for firms that undertake technological agreements, or collection of information and best practices to be passed on to firms in fairs, consortia, technological parks or industrial associations to reduce search costs of alliances and facilitate perfect match between partners.

Our study is not without limitations. Our findings may be specific to the data on Spanish firms. Indeed, Filippetti and Archibugi (2011) observe that the recent economic crisis had an effect on the innovation investments that vary across countries. Future works should examine the impact of cooperation in innovation activities on innovation performance across business cycles in other countries to assess the generalization of our results. Another limitation relates to the fact that we do not have details on the individual collaborations at the individual partner level, such as information on the start and end of the collaboration, the number of partners in each category, or whether they are new partners or not. Hence, future research should be devoted to collect and analyse the cooperation patterns of firms under different business climates at the 'dyadic' collaboration level (Belderbos et al. 2015). 
Table 1 - Number and share of firms by innovation and cooperation behaviour in selected years.

\begin{tabular}{lllllllllll}
\hline & 2004 & & 2006 & & 2008 & & 2010 & & 2012 \\
& $n$ & Share & $\#$ & Share & $\#$ & Share & $\#$ & Share & $\#$ & Share \\
\hline \hline Innovative firms* & 6042 & 71.60 & 7647 & 78.79 & 6925 & 76.07 & 6344 & 76.78 & 4991 & 66.46 \\
\hline Non-innovative & 2396 & 28.40 & 2058 & 21.21 & 2178 & 23.93 & 1919 & 23.22 & 2519 & 33.54 \\
\hline Total & $\mathbf{8 4 3 8}$ & $\mathbf{1 0 0}$ & $\mathbf{9 7 0 5}$ & $\mathbf{1 0 0}$ & $\mathbf{9 1 0 3}$ & $\mathbf{1 0 0}$ & $\mathbf{8 2 6 3}$ & $\mathbf{1 0 0}$ & $\mathbf{7 5 1 0}$ & $\mathbf{1 0 0}$ \\
\hline Cooperative innovative & 2282 & 37.77 & 2703 & 35.35 & 2416 & 34.89 & 2289 & 36.08 & 2080 & 41.68 \\
\hline Non-cooperative innovative & 3753 & 62.12 & 4944 & 64.65 & 4509 & 65.11 & 4055 & 63.92 & 2911 & 58.32 \\
\hline Missing & 7 & 0.12 & 0 & 0 & 0 & 0 & 0 & 0 & 0 & 0 \\
\hline Total & $\mathbf{6 0 4 2}$ & $\mathbf{1 0 0}$ & $\mathbf{7 6 4 7}$ & $\mathbf{1 0 0}$ & $\mathbf{6 9 2 5}$ & $\mathbf{1 0 0}$ & $\mathbf{6 3 4 4}$ & $\mathbf{1 0 0}$ & $\mathbf{4 9 9 1}$ & $\mathbf{1 0 0}$ \\
\hline
\end{tabular}

* which have product or/and process, and/or ongoing innovation 
Table 2 - Number and share of cooperative innovative firms by geographical location of partners and type of partners.

\begin{tabular}{|c|c|c|c|c|c|c|c|c|c|c|}
\hline & 2004 & & 2006 & & 2008 & & 2010 & & 2012 & \\
\hline & \# & Share & $\#$ & Share & $\#$ & Share & \# & Share & $\#$ & Share \\
\hline \multicolumn{11}{|l|}{ Geography } \\
\hline National only & 1410 & 61.79 & 1772 & 65.56 & 1526 & 63.16 & 1391 & 60.77 & 1236 & 59.42 \\
\hline International & 872 & 38.21 & 931 & 34.44 & 890 & 36.84 & 898 & 39.23 & 844 & 40.58 \\
\hline Total & 2282 & 100 & 2703 & 100 & 2416 & 100 & 2289 & 100 & 2080 & 100 \\
\hline \multicolumn{11}{|l|}{ Partners } \\
\hline Same group only & 150 & 6.57 & 154 & 5.70 & 125 & 5.17 & 97 & 4.24 & 188 & 9.04 \\
\hline Vertical only & 390 & 17.09 & 553 & 20.46 & 425 & 17.59 & 401 & 17.52 & 359 & 17.26 \\
\hline Horizontal only & 84 & 3.68 & 82 & 3.03 & 70 & 2.90 & 63 & 2.75 & 56 & 2.69 \\
\hline Institutional only & 672 & 29.45 & 780 & 28.86 & 681 & 28.19 & 606 & 26.47 & 431 & 20.72 \\
\hline Multi-partners & 986 & 43.21 & 1134 & 41.95 & 1115 & 46.15 & 1122 & 49.02 & 1046 & 50.29 \\
\hline Total & 2282 & 100 & 2703 & 100 & 2416 & 100 & 2289 & 100 & 2080 & 100 \\
\hline \multicolumn{11}{|l|}{ Geography and partners } \\
\hline National only+same group only & 98 & 4.29 & 102 & 3.77 & 70 & 2.90 & 53 & 2.32 & 112 & 5.38 \\
\hline National only+vertical only & 282 & 12.36 & 434 & 16.06 & 318 & 13.16 & 289 & 12.63 & 269 & 12.93 \\
\hline National only+horizontal only & 67 & 2.94 & 67 & 2.48 & 57 & 2.36 & 50 & 2.18 & 47 & 2.26 \\
\hline National only+institution only & 569 & 24.93 & 721 & 26.67 & 636 & 26.32 & 555 & 24.25 & 394 & 18.94 \\
\hline National only+multi-partners & 434 & 19.02 & 502 & 18.57 & 497 & 20.57 & 487 & 21.28 & 456 & 21.92 \\
\hline International+same group only & 52 & 2.28 & 52 & 1.92 & 55 & 2.28 & 44 & 1.92 & 76 & 3.65 \\
\hline International+vertical only & 108 & 4.73 & 119 & 4.40 & 107 & 4.43 & 112 & 4.89 & 90 & 4.33 \\
\hline International+horizontal only & 17 & 0.74 & 15 & 0.55 & 13 & 0.54 & 13 & 0.57 & 9 & 0.43 \\
\hline International+institution only & 103 & 4.51 & 59 & 2.18 & 45 & 1.86 & 51 & 2.23 & 37 & 1.78 \\
\hline International+multi-partners & 552 & 24.19 & 632 & 23.38 & 618 & 25.58 & 635 & 27.74 & 590 & 28.37 \\
\hline Total & 2282 & 100 & 2703 & 100 & 2416 & 100 & 2289 & 100 & 2080 & 100 \\
\hline
\end{tabular}


Table 3 - Descriptive statistics of the share of sales from new products by periods (balanced panel)

\begin{tabular}{|c|c|c|c|c|c|c|c|c|c|c|c|c|}
\hline & \multicolumn{4}{|c|}{ Whole period (2005-2013) } & \multicolumn{4}{|c|}{ Pre-crisis (2005-2010) } & \multicolumn{4}{|c|}{ During-crisis (2011-2013) } \\
\hline & $\begin{array}{l}\text { Overall } \\
\text { Mean }\end{array}$ & $\begin{array}{l}\text { Between } \\
\text { SD }\end{array}$ & $\begin{array}{l}\text { Within } \\
\text { SD }\end{array}$ & Median & $\begin{array}{l}\text { Overall } \\
\text { Mean }\end{array}$ & $\begin{array}{l}\text { Between } \\
\text { SD }\end{array}$ & $\begin{array}{l}\text { Within } \\
\text { SD }\end{array}$ & Median & $\begin{array}{l}\text { Overall } \\
\text { Mean }\end{array}$ & $\begin{array}{l}\text { Between } \\
\text { SD }\end{array}$ & $\begin{array}{l}\text { Within } \\
\text { SD }\end{array}$ & Median \\
\hline & \multicolumn{12}{|c|}{ New products } \\
\hline Innovative firms & 26.32 & 24.84 & 26.56 & 9.00 & 27.09 & 27.42 & 23.76 & 10 & 24.53 & 29.99 & 19.29 & 5 \\
\hline Cooperative innovative & 28.94 & 29.71 & 23.29 & 11.30 & 29.57 & 30.91 & 20.61 & 13 & 27.65 & 32.55 & 16.11 & 10 \\
\hline \multirow[t]{2}{*}{ Non-cooperative innovative } & 24.77 & 27.47 & 25.36 & 5.00 & 25.71 & 29.86 & 22.5 & 5 & 22.44 & 31.18 & 18.16 & 2 \\
\hline & \multicolumn{12}{|c|}{ New incremental-innovative products } \\
\hline Innovative firms & 15.66 & 18.82 & 21.82 & 1.00 & 16.04 & 20.88 & 19.65 & 1 & 14.78 & 23.29 & 16 & 0 \\
\hline Cooperative innovative & 15.99 & 22.67 & 18.49 & 3.00 & 16.44 & 23.16 & 16.93 & 4.2 & 15.06 & 24.74 & 12.21 & 2 \\
\hline \multirow[t]{2}{*}{ Non-cooperative innovative } & 15.47 & 21.29 & 21.27 & 0.00 & 15.82 & 23.22 & 18.81 & 0.1 & 14.59 & 24.79 & 15.74 & 0 \\
\hline & \multicolumn{12}{|c|}{ New radical-innovative products } \\
\hline Innovative firms & 10.65 & 15.21 & 17.29 & 0.00 & 11.04 & 16.94 & 15.9 & 0 & 9.75 & 18.65 & 12.35 & 0 \\
\hline Cooperative innovative & 12.95 & 19.27 & 16.56 & 0.10 & 13.12 & 20.61 & 14.78 & 0.5 & 12.59 & 21.43 & 11.98 & 0 \\
\hline Non-cooperative innovative & 9.30 & 16.75 & 15.83 & 0.00 & 9.88 & 18.45 & 14.52 & 0 & 7.84 & 18.71 & 10.68 & 0 \\
\hline
\end{tabular}


Table 4 - Description of the share of sales of new products of first-time cooperative innovative firms in the during crisis period and cooperative innovative firms only before the crisis, by periods (balanced panel).

\begin{tabular}{|c|c|c|c|c|c|c|c|c|c|c|c|c|}
\hline & \multicolumn{4}{|c|}{ Whole period (2005-2013) } & \multicolumn{4}{|c|}{ Pre-crisis (2004-2010) } & \multicolumn{4}{|c|}{ During-crisis (2011-2013) } \\
\hline & $\begin{array}{l}\text { Overall } \\
\text { Mean }\end{array}$ & $\begin{array}{l}\text { Between } \\
\text { SD }\end{array}$ & $\begin{array}{l}\text { Within } \\
\text { SD }\end{array}$ & Median & $\begin{array}{l}\text { Overall } \\
\text { Mean }\end{array}$ & $\begin{array}{l}\text { Between } \\
\text { SD }\end{array}$ & $\begin{array}{l}\text { Within } \\
\text { SD }\end{array}$ & Median & $\begin{array}{l}\text { Overall } \\
\text { Mean }\end{array}$ & $\begin{array}{l}\text { Between } \\
\text { SD }\end{array}$ & $\begin{array}{l}\text { Within } \\
\text { SD }\end{array}$ & Median \\
\hline & \multicolumn{12}{|c|}{ New products } \\
\hline $\begin{array}{l}\text { First-time cooperative innovative } \\
\text { in } 2010-2013(\# \text { 655) }\end{array}$ & 25.84 & 23.14 & 27.67 & 7.50 & 26.33 & 26.68 & 24.30 & 10.00 & 24.89 & 30.22 & 20.24 & 5.00 \\
\hline \multirow[t]{2}{*}{$\begin{array}{l}\text { Cooperative innovative in 2005- } \\
2008, \text { not afterwards }(\# 726)\end{array}$} & 26.08 & 24.99 & 27.25 & 5.00 & 27.45 & 27.81 & 24.74 & 8.00 & 22.42 & 30.52 & 2.00 & 0.10 \\
\hline & \multicolumn{12}{|c|}{ New incremental-innovative products } \\
\hline $\begin{array}{l}\text { First-time cooperative innovative } \\
\text { in } 2010-2013(\# \text { 655) }\end{array}$ & 14.93 & 17.4 & 21.99 & 0.5 & 15.2 & 20.5 & 19.25 & 0.8 & 14.39 & 23.1 & 16.25 & 0.1 \\
\hline \multirow[t]{2}{*}{$\begin{array}{l}\text { Cooperative innovative in 2005- } \\
2008, \text { not afterwards }(\# 726)\end{array}$} & 16.47 & 19.86 & 23.02 & 0.1 & 16.93 & 21.59 & 21.07 & 0.8 & 15.26 & 25.06 & 16.99 & 0 \\
\hline & \multicolumn{12}{|c|}{ New radical-innovative products } \\
\hline $\begin{array}{l}\text { First-time cooperative innovative } \\
\text { in } 2010-2013(\# \text { 655) }\end{array}$ & 10.91 & 14.81 & 18.56 & 0 & 11.12 & 17.25 & 16.48 & 0 & 10.5 & 18.7 & 14.09 & 0 \\
\hline $\begin{array}{l}\text { Cooperative innovative in 2005- } \\
2008 \text {, not afterwards }(\# 726)\end{array}$ & 9.6 & 14.62 & 17.45 & 0 & 10.51 & 16.65 & 16.65 & 0 & 7.16 & 18.47 & 10.68 & 0 \\
\hline
\end{tabular}


Table 5 - The relation between cooperation in innovation activities and innovation performance

\begin{tabular}{|c|c|c|c|c|c|}
\hline & (1) & (2) & (3) & (4) & (5) \\
\hline DV: Innovation sales & $\begin{array}{l}\text { Whole } \\
\text { period } \\
\text { (unbalanced) } \\
\text { Incremental }\end{array}$ & $\begin{array}{l}\text { Whole } \\
\text { period } \\
\text { (unbalanced) } \\
\text { Radical }\end{array}$ & $\begin{array}{l}\text { Whole } \\
\text { period } \\
\text { (balanced) } \\
\text { Radical }\end{array}$ & $\begin{array}{l}\text { Pre-crisis } \\
\text { (balanced) } \\
\text { Radical }\end{array}$ & $\begin{array}{l}\text { During-crisis } \\
\text { (balanced) } \\
\text { Radical }\end{array}$ \\
\hline cooperation & $\begin{array}{l}-0.004 \\
(0.054)\end{array}$ & $\begin{array}{l}0.379 * * * \\
(0.047)\end{array}$ & $\begin{array}{l}0.289 * * * \\
(0.056)\end{array}$ & $\begin{array}{l}0.134 * * \\
(0.062)\end{array}$ & $\begin{array}{l}0.636 * * * \\
(0.099)\end{array}$ \\
\hline in-house $R \& D$ intensity & $\begin{array}{l}-0.030 \\
(0.211)\end{array}$ & $\begin{array}{l}0.981 * * * \\
(0.230)\end{array}$ & $\begin{array}{l}1.424 * * * \\
(0.445)\end{array}$ & $\begin{array}{l}0.871 * \\
(0.482)\end{array}$ & $\begin{array}{l}2.955^{* * * *} \\
(0.840)\end{array}$ \\
\hline size & $\begin{array}{l}0.024 \\
(0.343)\end{array}$ & $\begin{array}{l}-0.549 * \\
(0.307)\end{array}$ & $\begin{array}{l}-0.155 \\
(0.479)\end{array}$ & $\begin{array}{l}-0.822 \\
(0.529)\end{array}$ & $\begin{array}{l}1.767 * * \\
(0.750)\end{array}$ \\
\hline size 2 & $\begin{array}{l}0.019 \\
(0.036)\end{array}$ & $\begin{array}{l}0.070 * * \\
(0.033)\end{array}$ & $\begin{array}{l}0.035 \\
(0.049)\end{array}$ & $\begin{array}{l}0.084 \\
(0.056)\end{array}$ & $\begin{array}{l}-0.109 \\
(0.070)\end{array}$ \\
\hline permanent $R \& D$ & $\begin{array}{l}0.147 \\
(0.091)\end{array}$ & $\begin{array}{l}0.356^{* * * *} \\
(0.087)\end{array}$ & $\begin{array}{l}0.294 * * * \\
(0.097)\end{array}$ & $\begin{array}{l}0.209 * \\
(0.111)\end{array}$ & $\begin{array}{l}0.454 * * \\
(0.178)\end{array}$ \\
\hline foreign & $\begin{array}{l}-0.089 \\
(0.191)\end{array}$ & $\begin{array}{l}-0.057 \\
(0.162)\end{array}$ & $\begin{array}{l}0.040 \\
(0.182)\end{array}$ & $\begin{array}{l}0.162 \\
(0.224)\end{array}$ & $\begin{array}{l}-0.322 \\
(0.380)\end{array}$ \\
\hline openness & $\begin{array}{l}0.036 * * \\
(0.017)\end{array}$ & $\begin{array}{l}0.027 * * \\
(0.014)\end{array}$ & $\begin{array}{l}0.010 \\
(0.015)\end{array}$ & $\begin{array}{l}0.009 \\
(0.019)\end{array}$ & $\begin{array}{l}0.013 \\
(0.029)\end{array}$ \\
\hline demand-pull & $\begin{array}{l}0.236 * * \\
(0.093)\end{array}$ & $\begin{array}{l}0.321 * * * \\
(0.066)\end{array}$ & $\begin{array}{l}0.362 * * * \\
(0.080)\end{array}$ & $\begin{array}{l}0.375^{* * *} \\
(0.102)\end{array}$ & $\begin{array}{l}0.388 * * * \\
(0.148)\end{array}$ \\
\hline international market & $\begin{array}{l}0.163 \\
(0.121)\end{array}$ & $\begin{array}{l}-0.074 \\
(0.128)\end{array}$ & $\begin{array}{l}-0.051 \\
(0.135)\end{array}$ & $\begin{array}{l}-0.010 \\
(0.171)\end{array}$ & $\begin{array}{l}0.002 \\
(0.285)\end{array}$ \\
\hline new firm & $\begin{array}{l}0.794 * * * \\
(0.158)\end{array}$ & $\begin{array}{l}0.322 * * \\
(0.161)\end{array}$ & $\begin{array}{l}0.079 \\
(0.203)\end{array}$ & $\begin{array}{l}-0.048 \\
(0.261)\end{array}$ & $\begin{array}{l}0.325 \\
(0.329)\end{array}$ \\
\hline market share & $\begin{array}{l}0.812 \\
(1.940)\end{array}$ & $\begin{array}{l}-0.369 \\
(1.827)\end{array}$ & $\begin{array}{l}-0.426 \\
(1.901)\end{array}$ & $\begin{array}{l}-0.569 \\
(2.194)\end{array}$ & $\begin{array}{l}2.607 \\
(6.644)\end{array}$ \\
\hline constant & $\begin{array}{l}-5.153 * * * \\
(1.294) \\
\end{array}$ & $\begin{array}{l}-6.097 * * * \\
(1.561)\end{array}$ & $\begin{array}{l}-11.637 * * * \\
(0.753)\end{array}$ & $\begin{array}{l}-11.025 * * * \\
(0.810)\end{array}$ & $\begin{array}{l}-8.652 * * * \\
(1.318)\end{array}$ \\
\hline $\begin{array}{l}\text { Observations } \\
\text { R-squared }\end{array}$ & $\begin{array}{l}41,176 \\
0.037\end{array}$ & $\begin{array}{l}41,176 \\
0.102\end{array}$ & $\begin{array}{l}30,138 \\
0.102\end{array}$ & $\begin{array}{l}20,955 \\
0.102\end{array}$ & $\begin{array}{l}9,183 \\
0.110\end{array}$ \\
\hline $\begin{array}{l}\text { Comparison test (balanced) } \\
\text { Cooperation }\end{array}$ & $\rho_{2005-2010-\rho}$ & 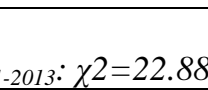 & & & \\
\hline
\end{tabular}

Bootstrapped standard errors in parentheses; industry dummies, inverse mills ratio and means-fixed effects are included. $* * * \mathrm{p}<0.01, * * \mathrm{p}<0.05, * \mathrm{p}<0.1$, n.s. non-significant

${ }^{\text {a }}$ Wald test on equality of coefficients in pooled estimations 
Table 6 - Cooperation in innovation activities by geography

\begin{tabular}{|c|c|c|c|c|}
\hline & (6) & (7) & $(8)$ & (9) \\
\hline $\begin{array}{l}\text { DV: Radical innovation } \\
\text { sales }\end{array}$ & $\begin{array}{l}\text { Whole period } \\
\text { (unbalanced) }\end{array}$ & $\begin{array}{l}\text { Whole period } \\
\text { (balanced) }\end{array}$ & $\begin{array}{l}\text { Pre-crisis } \\
\text { (balanced) }\end{array}$ & $\begin{array}{l}\text { During-crisis } \\
\text { (balanced) }\end{array}$ \\
\hline \multirow[t]{2}{*}{ national only } & $0.254 * * *$ & $0.178 * * *$ & 0.060 & $0.459 * * *$ \\
\hline & $(0.053)$ & $(0.069)$ & $(0.071)$ & $(0.121)$ \\
\hline \multirow[t]{2}{*}{ international } & $0.610 * * *$ & $0.486 * * *$ & $0.273 * * *$ & $0.925 * * *$ \\
\hline & $(0.066)$ & $(0.078)$ & $(0.089)$ & $(0.140)$ \\
\hline \multirow[t]{2}{*}{ in-house $R \& D$ intensity } & $0.984 * * *$ & $1.407 * * *$ & $0.858^{*}$ & $2.933 * * *$ \\
\hline & $(0.214)$ & $(0.415)$ & $(0.472)$ & $(0.835)$ \\
\hline \multirow[t]{2}{*}{ size } & $-0.560 * *$ & -0.158 & -0.818 & $1.737 * *$ \\
\hline & $(0.269)$ & $(0.411)$ & $(0.523)$ & $(0.843)$ \\
\hline \multirow[t]{2}{*}{ size 2} & $0.071 * *$ & 0.034 & 0.084 & -0.107 \\
\hline & $(0.029)$ & $(0.042)$ & $(0.056)$ & $(0.080)$ \\
\hline \multirow[t]{2}{*}{ permanent $\mathrm{R} \& \mathrm{D}$} & $0.351 * * *$ & $0.290 * * *$ & $0.206 * *$ & $0.451 * * *$ \\
\hline & $(0.075)$ & $(0.087)$ & $(0.104)$ & $(0.171)$ \\
\hline \multirow[t]{2}{*}{ foreign } & -0.063 & 0.032 & 0.154 & -0.314 \\
\hline & $(0.171)$ & $(0.192)$ & $(0.206)$ & $(0.369)$ \\
\hline \multirow[t]{2}{*}{ openness } & $0.026^{*}$ & 0.009 & 0.009 & 0.011 \\
\hline & $(0.014)$ & $(0.016)$ & $(0.020)$ & $(0.028)$ \\
\hline \multirow[t]{2}{*}{ demand-pull } & $0.317 * * *$ & $0.360 * * *$ & $0.375^{* * *}$ & $0.375^{* *}$ \\
\hline & $(0.069)$ & $(0.083)$ & $(0.088)$ & $(0.150)$ \\
\hline \multirow[t]{2}{*}{ international market } & -0.082 & -0.056 & -0.014 & -0.003 \\
\hline & $(0.115)$ & $(0.137)$ & $(0.173)$ & $(0.291)$ \\
\hline \multirow[t]{2}{*}{ new firm } & $0.321 * *$ & 0.074 & -0.048 & 0.305 \\
\hline & $(0.139)$ & $(0.190)$ & $(0.230)$ & $(0.326)$ \\
\hline \multirow[t]{2}{*}{ market share } & -0.376 & -0.444 & -0.634 & 2.595 \\
\hline & $(1.780)$ & $(1.891)$ & $(2.144)$ & $(6.535)$ \\
\hline \multirow[t]{2}{*}{ constant } & $-5.874 * * *$ & $-11.495 * * *$ & $-10.942 * * *$ & $-8.176 * * *$ \\
\hline & $(1.559)$ & $(0.804)$ & $(0.823)$ & $(1.346)$ \\
\hline Observations & 41,176 & 30,138 & 20,955 & 9,183 \\
\hline R-squared & 0.103 & 0.102 & 0.102 & 0.111 \\
\hline \multicolumn{5}{|l|}{ Comparison test $^{\mathrm{a}}$} \\
\hline national only & \multirow{2}{*}{\multicolumn{4}{|c|}{$\begin{array}{l}\beta_{2005-2010}=\beta_{2011-2013}: \chi 2=11.60 * * * \\
\beta_{2005-2010}=\beta_{2011-2013}: \chi 2=21.75 * * *\end{array}$}} \\
\hline international & & & & \\
\hline
\end{tabular}

Bootstrapped standard errors in parentheses; industry dummies, inverse mills ratio and means-fixed effects are included. $* * * \mathrm{p}<0.01, * * \mathrm{p}<0.05, * \mathrm{p}<0.1$, n.s. non-significant

${ }^{a}$ Wald test on equality of coefficients in pooled estimations 
Table 7- Cooperation in innovation activities by geography and type of partners

\begin{tabular}{|c|c|c|c|c|}
\hline DV: Radical innovation sales & $\begin{array}{l}\text { (10) Whole period } \\
\text { (unbalanced) }\end{array}$ & $\begin{array}{l}\text { (11) Whole period } \\
\text { (balanced) }\end{array}$ & $\begin{array}{l}\text { (12) Pre-crisis } \\
\text { (balanced) }\end{array}$ & $\begin{array}{l}\text { (13) During-crisis } \\
\text { (balanced) }\end{array}$ \\
\hline \multirow[t]{2}{*}{ national only+vertical only } & 0.015 & 0.110 & -0.065 & $0.503 * *$ \\
\hline & $(0.103)$ & $(0.122)$ & $(0.153)$ & $(0.216)$ \\
\hline \multirow[t]{2}{*}{ national only+horizontal only } & 0.032 & 0.146 & 0.351 & -0.158 \\
\hline & $(0.196)$ & $(0.259)$ & $(0.329)$ & $(0.378)$ \\
\hline \multirow[t]{2}{*}{ national only+institutional only } & $0.200 * *$ & $0.145^{*}$ & 0.017 & $0.432 * *$ \\
\hline & $(0.081)$ & $(0.088)$ & $(0.099)$ & $(0.171)$ \\
\hline \multirow[t]{2}{*}{ national only+multi-partners } & $0.554 * * *$ & $0.366^{* * *}$ & $0.225 * *$ & $0.701 * * *$ \\
\hline & $(0.079)$ & $(0.095)$ & $(0.112)$ & $(0.167)$ \\
\hline \multirow[t]{2}{*}{ international+vertical only } & $0.369 * *$ & $0.470 * * *$ & 0.235 & $0.938 * * *$ \\
\hline & $(0.157)$ & $(0.176)$ & $(0.203)$ & $(0.335)$ \\
\hline \multirow[t]{2}{*}{ international+horizontal only } & 0.030 & 0.067 & -0.245 & 0.884 \\
\hline & $(0.438)$ & $(0.540)$ & $(0.599)$ & $(1.033)$ \\
\hline \multirow[t]{2}{*}{ international+institutional only } & 0.305 & 0.125 & -0.226 & $0.964 * *$ \\
\hline & $(0.195)$ & $(0.255)$ & $(0.293)$ & $(0.451)$ \\
\hline \multirow{2}{*}{ international+multi-partners } & $0.726 * * *$ & $0.566 * * *$ & $0.367 * * *$ & $0.978 * * *$ \\
\hline & $(0.081)$ & $(0.085)$ & $(0.103)$ & $(0.153)$ \\
\hline \multirow[t]{2}{*}{ same group only } & 0.256 & -0.028 & -0.019 & 0.028 \\
\hline & $(0.168)$ & $(0.176)$ & $(0.238)$ & $(0.294)$ \\
\hline \multirow[t]{2}{*}{ in-house $R \& D$ intensity } & $0.970 * * *$ & $1.383 * * *$ & $0.842 *$ & $2.877 * * *$ \\
\hline & $(0.227)$ & $(0.416)$ & $(0.487)$ & $(0.820)$ \\
\hline \multirow[t]{2}{*}{ size } & $-0.551 *$ & -0.159 & -0.812 & $1.767 * *$ \\
\hline & $(0.319)$ & $(0.406)$ & $(0.537)$ & $(0.775)$ \\
\hline \multirow[t]{2}{*}{ size 2} & $0.070 * *$ & 0.034 & 0.083 & -0.110 \\
\hline & $(0.034)$ & $(0.043)$ & $(0.058)$ & $(0.076)$ \\
\hline \multirow[t]{2}{*}{ permanent $\mathrm{R} \& \mathrm{D}$} & $0.347 * * *$ & $0.290 * * *$ & $0.205^{*}$ & $0.451 * * *$ \\
\hline & $(0.072)$ & $(0.089)$ & $(0.105)$ & $(0.173)$ \\
\hline \multirow[t]{2}{*}{ foreign } & -0.061 & 0.031 & 0.153 & -0.331 \\
\hline & $(0.162)$ & $(0.176)$ & $(0.211)$ & $(0.364)$ \\
\hline \multirow[t]{2}{*}{ openness } & 0.022 & 0.007 & 0.006 & 0.009 \\
\hline & $(0.014)$ & $(0.016)$ & $(0.018)$ & $(0.028)$ \\
\hline demand-pull & $0.315^{* * *}$ & $0.357 * * *$ & $0.373 * * *$ & $0.372 * * *$ \\
\hline & $(0.073)$ & $(0.076)$ & $(0.098)$ & $(0.135)$ \\
\hline international market & -0.080 & -0.052 & -0.012 & 0.009 \\
\hline & $(0.117)$ & $(0.146)$ & $(0.161)$ & $(0.292)$ \\
\hline new firm & $0.317 * *$ & 0.078 & -0.039 & 0.297 \\
\hline & $(0.138)$ & $(0.197)$ & $(0.237)$ & $(0.330)$ \\
\hline market share & -0.363 & -0.451 & -0.650 & 2.561 \\
\hline & $(1.851)$ & $(1.809)$ & $(2.098)$ & $(6.366)$ \\
\hline constant & $-5.711 * * *$ & $-11.432 * * *$ & $-10.847 * * *$ & $-7.828 * * *$ \\
\hline & $(1.550)$ & $(0.802)$ & $(0.812)$ & $(1.260)$ \\
\hline Observations & 41,176 & 30,138 & 20,955 & 9,183 \\
\hline R-squared & 0.103 & 0.102 & 0.103 & 0.112 \\
\hline \multicolumn{5}{|l|}{ Comparison test $^{\mathrm{a}}$} \\
\hline national only +vertical only & $\beta_{2005-2010}=\beta_{2011-2013}:$ & $\chi 2=4.92 * *$ & & \\
\hline national only+horizontal only & $\beta_{2005-2010}=\beta_{2011-2013}:$ & $\chi^{2}=1.07$ n.s.. & & \\
\hline national only+institutional only & $\beta_{2005-2010}=\beta_{2011-2013}:$ & $\chi^{2}=6.31 * *$ & & \\
\hline national only + multi-partners & $\beta_{2005-2010}=\beta_{2011-2013}:$ & $\chi^{2}=7.75 * * *$ & & \\
\hline international+vertical only & $\beta_{2005-2010}=\beta_{2011-2013}:$ & $\chi^{2}=4.11 * *$ & & \\
\hline international+horizontal only & $\beta_{2005-2010}=\beta_{2011-2013:}$ & $\chi^{2}=0.99$ n.s. & & \\
\hline international+institutional only & $\beta_{2005-2010}=\beta_{2011-2013}:$ & $\chi^{2}=4.58 * *$ & & \\
\hline international + multi-partners & $\beta_{2005-2010}=\beta_{2011-2013}:$ & $\chi^{2}=18.00 * * *$ & & \\
\hline
\end{tabular}


Table 8 - The impact of experience in cooperation in innovation activities on innovation performance in the during-crisis period (2011-13), balanced panel

\begin{tabular}{|c|c|c|}
\hline $\begin{array}{l}\text { DV: Radical innovation } \\
\text { sales }\end{array}$ & $\begin{array}{l}\text { (14) } \\
\text { During crisis }\end{array}$ & $\begin{array}{l}\text { (15) } \\
\text { During crisis }\end{array}$ \\
\hline continuity & $\begin{array}{l}0.052 * * * \\
(0.017)\end{array}$ & \\
\hline during-crisis cooperation & & $\begin{array}{l}0.718 * * * \\
(0.140)\end{array}$ \\
\hline before-crisis cooperation & & $\begin{array}{l}-0.015 \\
(0.135)\end{array}$ \\
\hline persistent cooperation & & $\begin{array}{l}0.957 * * * \\
(0.197)\end{array}$ \\
\hline in-house $R \& D$ intensity & $\begin{array}{l}3.070 * * * \\
(0.845)\end{array}$ & $\begin{array}{l}3.042 * * * \\
(0.835)\end{array}$ \\
\hline size & $\begin{array}{l}1.889 * * \\
(0.842)\end{array}$ & $\begin{array}{l}1.336 \\
(0.887)\end{array}$ \\
\hline size 2 & $\begin{array}{l}-0.116 \\
(0.079)\end{array}$ & $\begin{array}{l}-0.064 \\
(0.086)\end{array}$ \\
\hline permanent R\&D & $\begin{array}{l}0.492 * * * \\
(0.172)\end{array}$ & $\begin{array}{l}0.519 * * * \\
(0.196)\end{array}$ \\
\hline foreign & $\begin{array}{l}-0.348 \\
(0.372)\end{array}$ & $\begin{array}{l}-0.253 \\
(0.408)\end{array}$ \\
\hline openness & $\begin{array}{l}0.020 \\
(0.027)\end{array}$ & $\begin{array}{l}0.001 \\
(0.029)\end{array}$ \\
\hline demand-pull & $\begin{array}{l}0.441 * * * \\
(0.144)\end{array}$ & $\begin{array}{l}0.341 * * \\
(0.165)\end{array}$ \\
\hline international market & $\begin{array}{l}0.016 \\
(0.295)\end{array}$ & $\begin{array}{l}-0.127 \\
(0.301)\end{array}$ \\
\hline new firm & $\begin{array}{l}0.295 \\
(0.337)\end{array}$ & $\begin{array}{l}0.314 \\
(0.292)\end{array}$ \\
\hline market share & $\begin{array}{l}2.442 \\
(6.720)\end{array}$ & $\begin{array}{l}-4.490 \\
(5.438)\end{array}$ \\
\hline constant & $\begin{array}{l}-8.375^{* * *} \\
(1.404)\end{array}$ & $\begin{array}{l}-10.803 * * * \\
(1.236)\end{array}$ \\
\hline Observations & 9,183 & 8,129 \\
\hline R-squared & 0.107 & 0.120 \\
\hline
\end{tabular}

Bootstrapped standard errors in parentheses; industry dummies, inverse mills ratio and means-fixed effects are included. $* * * \mathrm{p}<0.01, * * \mathrm{p}<0.05, * \mathrm{p}<0.1$ 


\section{Appendix}

\section{A1 - Description of variables}

\begin{tabular}{|c|c|}
\hline Variables & Description \\
\hline \multicolumn{2}{|l|}{ Dependent variables } \\
\hline innovation & $\begin{array}{l}1 \text { if the firm has carried out any of these innovation activities: internal R\&D; } \\
\text { external R\&D, acquisition of machinery, equipment and software; acquisition of } \\
\text { other external knowledge; training; market introduction of innovations; other } \\
\text { preparations. }\end{array}$ \\
\hline radical innovation performance & $\begin{array}{l}\text { Share of sales of new or significantly improved products new to the market (log[new } \\
\text { sales/(1-new sales)]) }\end{array}$ \\
\hline $\begin{array}{l}\text { incremental innovation } \\
\text { performance }\end{array}$ & $\begin{array}{l}\text { Share of sales of new or significantly improved products new to the firm }(\log [\text { new } \\
\text { sales/(1-new sales)]) }\end{array}$ \\
\hline \multicolumn{2}{|l|}{ Independent variables } \\
\hline cooperation & $\begin{array}{l}\text { Any type of cooperation in innovation activities in the previous three years (1-year } \\
\text { lag) }\end{array}$ \\
\hline national only & Cooperation in innovation activities only with national partners (1-year lag) \\
\hline international & Cooperation in innovation activities with international partners (1-year lag) \\
\hline national only+vertical only & Cooperation in innovation activities only with national vertical partners (1-year lag) \\
\hline national only+horizontal only & $\begin{array}{l}\text { Cooperation in innovation activities only with national horizontal partners (1-year } \\
\text { lag) }\end{array}$ \\
\hline national only+institutional only & $\begin{array}{l}\text { Cooperation in innovation activities only with national institutional partners (1-year } \\
\text { lag) }\end{array}$ \\
\hline national only+multi-partners & $\begin{array}{l}\text { Cooperation in innovation activities with at least two national partners not from the } \\
\text { same group (1-year lag) }\end{array}$ \\
\hline international+ vertical only & $\begin{array}{l}\text { Cooperation in innovation activities only with vertical partners of which at least } 1 \text { is } \\
\text { international (1-year lag) }\end{array}$ \\
\hline international+horizontal only & $\begin{array}{l}\text { Cooperation in innovation activities only with horizontal partners of which at least } 1 \\
\text { is international (1-year lag) }\end{array}$ \\
\hline international+institutional only & $\begin{array}{l}\text { Cooperation in innovation activities only with institutional partners of which at least } \\
1 \text { is international (1-year lag) }\end{array}$ \\
\hline international+multi-partners & $\begin{array}{l}\text { Cooperation in innovation activities with any partners (not from the same group) of } \\
\text { which at least } 1 \text { is international (1-year lag) }\end{array}$ \\
\hline same group only & $\begin{array}{l}\text { Cooperation in innovation activities only with partner from the same group (either } \\
\text { national or international) (1-year lag) }\end{array}$ \\
\hline continuity & $\begin{array}{l}\text { Number of years up to } t-1 \text { in which the firm has declared any cooperation in } \\
\text { innovation activities }\end{array}$ \\
\hline persistent cooperation & If the firm has declared any R\&D collaboration in $2005-2008$, and in $t-1$ \\
\hline after crisis cooperation & If the firm has not declared any R\&D collaboration in $2005-2008$, and it has in $t-1$ \\
\hline before crisis cooperation & If the firm has declared any R\&D collaboration in $2005-2008$, and not in $t-1$ \\
\hline size & Logarithm of number of employees (1-year lag) \\
\hline size 2 & Logarithm of number of employees (squared) (1-year lag) \\
\hline market share & $\begin{array}{l}\text { Ratio of the sales of a firm over the total sales of the two-digit industry it belongs to } \\
\text { (1-year lag) }\end{array}$ \\
\hline in-house intensity & Ratio between intramural R\&D expenditure and turnover (1-year lag) \\
\hline foreign & $\begin{array}{l}1 \text { if the headquarter of the firm is outside Spain and it has at least a 50\% of foreign } \\
\text { capital (1-year lag) }\end{array}$ \\
\hline permanent R\&D & 1 if the firm reported that it performed internal R\&D continuously (1-year lag) \\
\hline openness & $\begin{array}{l}\text { Number of information sources for innovations that the firm had used in the } \\
\text { previous three years (from within the firm or group, suppliers, clients, competitors, } \\
\text { private R\&D institutions, conferences, scientific reviews or professional } \\
\text { associations) (1-year lag) }\end{array}$ \\
\hline demand-pull & $\begin{array}{l}1 \text { if at least one of the following demand-enhancing objectives for the firm's } \\
\text { innovations in the previous three years is given the highest score [number between } 1 \\
\text { (not important) and } 4 \text { (very important)]: extend product range; increase market or }\end{array}$ \\
\hline
\end{tabular}


market share; improve quality in goods and services (1-year lag)

\begin{tabular}{ll}
\hline international market & $\begin{array}{l}1 \text { if the firm has sold its products in markets other than local or national in the } \\
\text { previous three years (1-year lag) }\end{array}$ \\
\hline new firm & $\begin{array}{l}\text { 1 if the firm was newly created in anytime during the survey year or in the previous } \\
\text { two years (survey year considered are 2004 and 2005) }\end{array}$ \\
\hline cost obstacles & $\begin{array}{l}\text { Sum of the scores of importance that the firm attributed [number between 1 (not } \\
\text { important) and 4 (very important)] to the following factors that hampered its } \\
\text { innovation activities in the previous three years: lack of funds within the enterprise } \\
\text { or enterprise group; lack of finance from sources outside the enterprise; innovation } \\
\text { costs too high. Rescaled from 0 (unimportant) to 1 (crucial) (1-year lag) }\end{array}$ \\
\hline knowledge obstacles & $\begin{array}{l}\text { Sum of the scores of importance that the firm attributed [number between 1 (not } \\
\text { important) and 4 (very important)] to the following factors that hampered its } \\
\text { innovation activities in the previous three years: lack of qualified personnel; lack of } \\
\text { information on technology; lack of information on markets; difficulty in finding } \\
\text { cooperation partners for innovation. Rescaled from 0 (unimportant) to 1 (crucial) (1- } \\
\text { year lag) }\end{array}$ \\
\hline $\begin{array}{l}\text { Sum of the scores of importance that the firm attributed [number between 1 (not } \\
\text { important) and 4 (very important)] to the following factors that hampered its } \\
\text { innovation activities in the previous three years: markets dominated by established } \\
\text { enterprises; uncertain demand for innovative goods or services. Rescaled from 0 } \\
\text { (unimportant) to 1 (crucial) (1-year lag) }\end{array}$ \\
$\begin{array}{l}\text { Sum of the scores of importance that the firm attributed [number between 1 (not } \\
\text { important) and 4 (very important)] to the following factors that hampered its } \\
\text { innovation activities in the previous three years: not necessary due to previous } \\
\text { innovations; not necessary due to the absence of demand. Rescaled from 0 } \\
\text { (unimportant) to 1 (crucial) (1-year lag) }\end{array}$ \\
\begin{tabular}{l} 
1 if the firm belongs to a group of enterprises (1-year lag) \\
\hline other obstacles
\end{tabular}
\end{tabular}




\begin{tabular}{|c|c|c|c|c|c|c|c|c|c|c|c|c|c|c|}
\hline 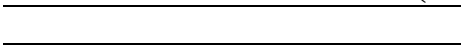 & 1 & 2 & 3 & 4 & 5 & 6 & 7 & 8 & 9 & 10 & 11 & 12 & 13 & 14 \\
\hline 1 cooperation & 1 & & & & & & & & & & & & & \\
\hline 2 national only & $\begin{array}{l}0.720 \\
* * *\end{array}$ & 1 & & & & & & & & & & & & \\
\hline 3 international & $\begin{array}{l}0.521 \\
* * *\end{array}$ & $\begin{array}{l}-0.152 \\
* * *\end{array}$ & 1 & & & & & & & & & & & \\
\hline 4 national only+vertical only & $\begin{array}{l}0.299 \\
* * *\end{array}$ & $\begin{array}{l}0.397 \\
* * *\end{array}$ & $\begin{array}{l}-0.027 \\
* * *\end{array}$ & 1 & & & & & & & & & & \\
\hline 5 national only+horizontal only & $\begin{array}{l}0.126 \\
* * *\end{array}$ & $\begin{array}{l}0.178 \\
* * *\end{array}$ & $\begin{array}{l}-0.023 \\
* * *\end{array}$ & $\begin{array}{l}-0.016 \\
* * *\end{array}$ & 1 & & & & & & & & & \\
\hline 6 national only+institutional only & $\begin{array}{l}0.417 \\
* * *\end{array}$ & $\begin{array}{l}0.562 \\
* * *\end{array}$ & $\begin{array}{l}-0.052 \\
* * *\end{array}$ & $\begin{array}{l}-0.052 \\
* * *\end{array}$ & $\begin{array}{l}-0.022 \\
* * *\end{array}$ & 1 & & & & & & & & \\
\hline 7 national only+multi-partners & $\begin{array}{l}0.375 \\
* * *\end{array}$ & $\begin{array}{l}0.534 \\
* * *\end{array}$ & $\begin{array}{l}-0.081 \\
* * *\end{array}$ & $\begin{array}{l}-0.047 \\
* * *\end{array}$ & $\begin{array}{l}-0.020 \\
* * *\end{array}$ & $\begin{array}{l}-0.065 \\
* * *\end{array}$ & 1 & & & & & & & \\
\hline 8 international+vertical only & $\begin{array}{l}0.170 \\
* * *\end{array}$ & $\begin{array}{l}-0.050 \\
* * *\end{array}$ & $\begin{array}{l}0.331 \\
* * *\end{array}$ & $\begin{array}{l}-0.021 \\
* * *\end{array}$ & $\begin{array}{l}-0.009 \\
* *\end{array}$ & $\begin{array}{l}-0.030 \\
* * *\end{array}$ & $\begin{array}{l}-0.027 \\
* * *\end{array}$ & 1 & & & & & & \\
\hline 9 international+horizontal only & $\begin{array}{l}0.058 \\
* * *\end{array}$ & $\begin{array}{l}-0.017 \\
* * *\end{array}$ & $\begin{array}{l}0.114 \\
* * *\end{array}$ & $\begin{array}{l}-0.007 \\
* *\end{array}$ & -0.003 & $\begin{array}{l}-0.010 \\
* * *\end{array}$ & $\begin{array}{l}-0.009 \\
* *\end{array}$ & -0.004 & 1 & & & & & \\
\hline 10 international+institutional only & $\begin{array}{l}0.123 \\
* * *\end{array}$ & $\begin{array}{l}-0.036 \\
* * *\end{array}$ & $\begin{array}{l}0.240 \\
* * *\end{array}$ & $\begin{array}{l}-0.015 \\
* * *\end{array}$ & $\begin{array}{l}-0.006 \\
*\end{array}$ & $\begin{array}{l}-0.021 \\
* * *\end{array}$ & $\begin{array}{l}-0.019 \\
* * *\end{array}$ & $\begin{array}{l}-0.009 \\
* *\end{array}$ & -0.003 & 1 & & & & \\
\hline 11 international+multi-partners & $\begin{array}{l}0.422 \\
* * *\end{array}$ & $\begin{array}{l}-0.124 \\
* * *\end{array}$ & $\begin{array}{l}0.814 \\
* * *\end{array}$ & $\begin{array}{l}-0.053 \\
* * *\end{array}$ & $\begin{array}{l}-0.022 \\
* * *\end{array}$ & $\begin{array}{l}-0.073 \\
* * *\end{array}$ & $\begin{array}{l}-0.066 \\
* * *\end{array}$ & $\begin{array}{l}-0.030 \\
* * *\end{array}$ & $\begin{array}{l}-0.010 \\
* * *\end{array}$ & $\begin{array}{l}-0.022 \\
* * *\end{array}$ & 1 & & & \\
\hline 12 same group only & $\begin{array}{l}0.195 \\
* * *\end{array}$ & $\begin{array}{l}0.146 \\
* * *\end{array}$ & $\begin{array}{l}0.124 \\
* * *\end{array}$ & $\begin{array}{l}-0.024 \\
* * *\end{array}$ & $\begin{array}{l}-0.010 \\
* * *\end{array}$ & $\begin{array}{l}-0.034 \\
* * *\end{array}$ & $\begin{array}{l}-0.031 \\
* * *\end{array}$ & $\begin{array}{l}-0.014 \\
* * *\end{array}$ & -0.004 & $\begin{array}{l}-0.010 \\
* * *\end{array}$ & $\begin{array}{l}-0.034 \\
* * *\end{array}$ & 1 & & \\
\hline 13 continuity & $\begin{array}{l}0.620 \\
* * *\end{array}$ & $\begin{array}{l}0.414 \\
* * *\end{array}$ & $\begin{array}{l}0.432 \\
* * *\end{array}$ & $\begin{array}{l}0.147 \\
* * *\end{array}$ & $\begin{array}{l}0.055 \\
* * *\end{array}$ & $\begin{array}{l}0.241 \\
* * *\end{array}$ & $\begin{array}{l}0.269 \\
* * *\end{array}$ & $\begin{array}{l}0.109 \\
* * *\end{array}$ & $\begin{array}{l}0.030 \\
* * *\end{array}$ & $\begin{array}{l}0.075 \\
* * *\end{array}$ & $\begin{array}{l}0.391 \\
* * *\end{array}$ & $\begin{array}{l}0.102 \\
* * *\end{array}$ & 1 & \\
\hline 14 persistent cooperation & $\begin{array}{l}0.952 \\
* * *\end{array}$ & $\begin{array}{l}0.681 \\
* * *\end{array}$ & $\begin{array}{l}0.515 \\
* * *\end{array}$ & $\begin{array}{l}0.274 \\
* * *\end{array}$ & $\begin{array}{l}0.121 \\
* * *\end{array}$ & $\begin{array}{l}0.403 \\
* * *\end{array}$ & $\begin{array}{l}0.360 \\
* * *\end{array}$ & $\begin{array}{l}0.161 \\
* * *\end{array}$ & $\begin{array}{l}0.052 \\
* * *\end{array}$ & $\begin{array}{l}0.122 \\
* * *\end{array}$ & $\begin{array}{l}0.424 \\
* * *\end{array}$ & $\begin{array}{l}0.176 \\
* * *\end{array}$ & $\begin{array}{l}0.636 \\
* * *\end{array}$ & 1 \\
\hline
\end{tabular}


[cont.]

\begin{tabular}{|c|c|c|c|c|c|c|c|c|c|c|c|c|c|c|c|c|c|c|c|c|c|c|c|c|c|c|c|}
\hline & & 1 & 2 & 3 & 4 & 5 & 6 & 7 & 8 & 9 & 10 & 11 & 12 & 13 & 14 & 15 & 16 & 17 & 18 & 19 & 20 & 21 & 22 & 23 & 24 & 25 & 26 \\
\hline 15 & $\begin{array}{l}\text { after crisis } \\
\text { cooperation }\end{array}$ & $\begin{array}{l}0.190 \\
* * *\end{array}$ & $\begin{array}{l}0.175 \\
* * *\end{array}$ & $\begin{array}{l}0.064 \\
* * *\end{array}$ & $\begin{array}{l}0.106 \\
* * *\end{array}$ & $\begin{array}{l}0.029 \\
* * *\end{array}$ & $\begin{array}{l}0.078 \\
* * *\end{array}$ & $\begin{array}{l}0.075 \\
* * *\end{array}$ & $\begin{array}{l}0.048 \\
* * *\end{array}$ & $\begin{array}{l}0.030 \\
* * *\end{array}$ & $\begin{array}{l}0.011 \\
* * *\end{array}$ & $\begin{array}{l}0.026 \\
* * *\end{array}$ & $\begin{array}{l}0.081 \\
* * *\end{array}$ & $\begin{array}{l}0.010 \\
* *\end{array}$ & $\begin{array}{l}-0.101 \\
* * *\end{array}$ & 1 & & & & & & & & & & & \\
\hline 16 & $\begin{array}{l}\text { before crisis } \\
\text { cooperation }\end{array}$ & $\begin{array}{l}-0.47 \\
* * *\end{array}$ & $\begin{array}{l}-0.286 \\
* * *\end{array}$ & $\begin{array}{l}-0.208 \\
* * *\end{array}$ & $\begin{array}{l}-0.119 \\
* * *\end{array}$ & $\begin{array}{l}-0.050 \\
* * *\end{array}$ & $\begin{array}{l}-0.166 \\
* * *\end{array}$ & $\begin{array}{l}-0.149 \\
* * *\end{array}$ & $\begin{array}{l}-0.068 \\
* * *\end{array}$ & $\begin{array}{l}-0.023 \\
* * *\end{array}$ & $\begin{array}{l}-0.049 \\
* * *\end{array}$ & $\begin{array}{l}-0.168 \\
* * *\end{array}$ & $\begin{array}{l}8-0.078 \\
* * *\end{array}$ & $\begin{array}{l}0.032 \\
* * *\end{array}$ & $\begin{array}{l}-0.378 \\
* * *\end{array}$ & $\begin{array}{l}-0.078 \\
* * *\end{array}$ & & & & & & & & & & & \\
\hline 17 & $\begin{array}{l}\text { in-house } R \& D \\
\text { intensity }\end{array}$ & $\begin{array}{l}0.151 \\
* * *\end{array}$ & $\begin{array}{l}0.075 \\
* * *\end{array}$ & $\begin{array}{l}0.191 \\
* * *\end{array}$ & $\begin{array}{l}-0.007 \\
* *\end{array}$ & 0.004 & $\begin{array}{l}0.038 \\
* * *\end{array}$ & $\begin{array}{l}0.085 \\
* * *\end{array}$ & $\begin{array}{l}-0.007 \\
* *\end{array}$ & $\begin{array}{l}0.007 \\
* *\end{array}$ & $\begin{array}{l}0.043 \\
* * *\end{array}$ & $\begin{array}{l}0.220 \\
* * *\end{array}$ & $\begin{array}{l}-0.008 \\
* *\end{array}$ & $\begin{array}{l}0.182 \\
* * *\end{array}$ & $\begin{array}{l}0.183 \\
* * *\end{array}$ & -0.003 & $\begin{array}{l}-0.029 \\
* * *\end{array}$ & & & & & & & & & & \\
\hline 18 & size & $\begin{array}{l}0.112 \\
* * *\end{array}$ & $\begin{array}{l}-0.034 \\
* * *\end{array}$ & $\begin{array}{l}0.110 \\
* * *\end{array}$ & $\begin{array}{l}0.007 \\
* *\end{array}$ & $\begin{array}{l}-0.007 \\
* *\end{array}$ & $\begin{array}{l}-0.056 \\
* * *\end{array}$ & 0.002 & $\begin{array}{l}0.022 \\
* * *\end{array}$ & $\begin{array}{l}-0.010 \\
* * *\end{array}$ & 0.004 & $\begin{array}{l}0.092 \\
* * *\end{array}$ & $\begin{array}{l}0.058 \\
* * *\end{array}$ & $\begin{array}{l}0.043 \\
* * *\end{array}$ & $\begin{array}{l}0.111 \\
* * *\end{array}$ & $\begin{array}{l}0.030 \\
* * *\end{array}$ & -0.004 & $\begin{array}{l}-0.153 \\
* * *\end{array}$ & & & & & & & & & \\
\hline 19 & size 2 & $\begin{array}{l}0.114 \\
* * *\end{array}$ & $\begin{array}{l}-0.031 \\
* * *\end{array}$ & $\begin{array}{l}0.107 \\
* *\end{array}$ & $\begin{array}{l}0.007 \\
* *\end{array}$ & -0.005 & $\begin{array}{l}-0.057 \\
* * *\end{array}$ & $\begin{array}{l}0.007 \\
*\end{array}$ & $\begin{array}{l}0.021 \\
* * *\end{array}$ & $\begin{array}{l}-0.010 \\
* * *\end{array}$ & 0.002 & $\begin{array}{l}0.091 \\
* * *\end{array}$ & $\begin{array}{l}0.055 \\
* * *\end{array}$ & $\begin{array}{l}0.042 \\
* * *\end{array}$ & $\begin{array}{l}0.110 \\
* * *\end{array}$ & $\begin{array}{l}0.029 \\
* * *\end{array}$ & $\begin{array}{l}-0.009 \\
* *\end{array}$ & $\begin{array}{l}-0.139 \\
* * *\end{array}$ & $\begin{array}{l}0.981 \\
* * *\end{array}$ & 1 & & & & & & & \\
\hline 20 & permanent $R \& D$ & $\begin{array}{l}0.230 \\
* * *\end{array}$ & $\begin{array}{l}0.198 \\
* * *\end{array}$ & $\begin{array}{l}0.280 \\
* * *\end{array}$ & $\begin{array}{l}0.021 \\
* * *\end{array}$ & $\begin{array}{l}0.026 \\
* * *\end{array}$ & $\begin{array}{l}0.132 \\
* * *\end{array}$ & $\begin{array}{l}0.159 \\
* * *\end{array}$ & $\begin{array}{l}0.059 \\
* * *\end{array}$ & $\begin{array}{l}0.030 \\
* * *\end{array}$ & $\begin{array}{l}0.069 \\
* * *\end{array}$ & $\begin{array}{l}0.261 \\
* * *\end{array}$ & $\begin{array}{l}0.026 \\
* * *\end{array}$ & $\begin{array}{l}0.310 \\
* * *\end{array}$ & $\begin{array}{l}0.311 \\
* * *\end{array}$ & $\begin{array}{l}0.011 \\
* * *\end{array}$ & $\begin{array}{l}0.014 \\
* * *\end{array}$ & $\begin{array}{l}0.265 \\
* * *\end{array}$ & $\begin{array}{l}-0.048 \\
* * *\end{array}$ & $\begin{array}{l}-0.056 \\
* * *\end{array}$ & & & & & & & \\
\hline 21 & foreign & $\begin{array}{l}0.030 \\
* * *\end{array}$ & $\begin{array}{l}-0.076 \\
* * *\end{array}$ & $\begin{array}{l}0.135 \\
*\end{array}$ & $\begin{array}{l}0.006 \\
*\end{array}$ & $\begin{array}{l}-0.017 \\
* * *\end{array}$ & $\begin{array}{l}-0.025 \\
* * *\end{array}$ & $\begin{array}{l}-0.052 \\
* * *\end{array}$ & $\begin{array}{l}0.040 \\
* * *\end{array}$ & -0.005 & $\begin{array}{l}0.010 \\
* * *\end{array}$ & $\begin{array}{l}0.053 \\
* * *\end{array}$ & $\begin{array}{l}0.097 \\
* * *\end{array}$ & $\begin{array}{l}0.035 \\
* * *\end{array}$ & $\begin{array}{l}0.041 \\
* * *\end{array}$ & $\begin{array}{l}0.013 \\
* * *\end{array}$ & $\begin{array}{l}0.016 \\
* * *\end{array}$ & $\begin{array}{l}-0.063 \\
* * *\end{array}$ & $\begin{array}{l}0.254 \\
* * *\end{array}$ & $\begin{array}{l}0.242 \\
* * *\end{array}$ & 0.003 & 1 & & & & & \\
\hline 22 & openness & $\begin{array}{l}0.229 \\
* * *\end{array}$ & $\begin{array}{l}0.111 \\
* * *\end{array}$ & $\begin{array}{l}0.196 \\
* * *\end{array}$ & -0.017 & 0.007 & $\begin{array}{l}0.055 \\
* * *\end{array}$ & $\begin{array}{l}0.128 \\
* * *\end{array}$ & $\begin{array}{l}0.017 \\
* * *\end{array}$ & $\begin{array}{l}0.008 \\
*\end{array}$ & $\begin{array}{l}0.023 \\
* * *\end{array}$ & $\begin{array}{l}0.210 \\
* * *\end{array}$ & -0.004 & $\begin{array}{l}0.243 \\
* * *\end{array}$ & $\begin{array}{l}0.231 \\
* * *\end{array}$ & $\begin{array}{l}0.017 \\
* * *\end{array}$ & $\begin{array}{l}-0.057 \\
* * *\end{array}$ & $\begin{array}{l}0.091 \\
* * *\end{array}$ & $\begin{array}{l}0.055 \\
* * *\end{array}$ & $\begin{array}{l}0.052 \\
* * *\end{array}$ & $\begin{array}{l}0.220 \\
* * *\end{array}$ & $\begin{array}{l}-0.009 \\
* *\end{array}$ & & & & & \\
\hline 23 & demand-pull & $\begin{array}{l}0.124 \\
* * *\end{array}$ & $\begin{array}{l}0.053 \\
* * *\end{array}$ & $\begin{array}{l}0.106 \\
* *\end{array}$ & $\begin{array}{l}0.011 \\
* *\end{array}$ & $\begin{array}{l}0.007 \\
* * *\end{array}$ & $\begin{array}{l}0.016 \\
* * *\end{array}$ & $\begin{array}{l}0.058 \\
* * *\end{array}$ & $\begin{array}{l}0.032 \\
* * *\end{array}$ & $\begin{array}{l}0.011 \\
* *\end{array}$ & 0.003 & $\begin{array}{l}0.106 \\
* * *\end{array}$ & -0.003 & $\begin{array}{l}0.143 \\
* * *\end{array}$ & $\begin{array}{l}0.119 \\
* * *\end{array}$ & $\begin{array}{l}0.031 \\
* * *\end{array}$ & $\begin{array}{l}-0.042 \\
* * *\end{array}$ & $\begin{array}{l}0.032 \\
* * *\end{array}$ & $\begin{array}{l}-0.024 \\
* * *\end{array}$ & $\begin{array}{l}-0.023 \\
* * *\end{array}$ & $\begin{array}{l}0.126 \\
* * *\end{array}$ & -0.005 & $\begin{array}{l}0.263 \\
* * *\end{array}$ & 1 & & & \\
\hline 24 & $\begin{array}{l}\text { international } \\
\text { market }\end{array}$ & $\begin{array}{l}0.055 \\
* * *\end{array}$ & $\begin{array}{l}0.038 \\
* * *\end{array}$ & $\begin{array}{l}0.151 \\
* * *\end{array}$ & $\begin{array}{l}-0.003 \\
*\end{array}$ & $\begin{array}{l}-0.006 \\
*\end{array}$ & $\begin{array}{l}0.050 \\
* * *\end{array}$ & $\begin{array}{l}0.021 \\
* * *\end{array}$ & $\begin{array}{l}0.050 \\
* *\end{array}$ & $\begin{array}{l}0.009 \\
* *\end{array}$ & $\begin{array}{l}0.031 \\
* * *\end{array}$ & $\begin{array}{l}0.124 \\
* * *\end{array}$ & $\begin{array}{l}0.029 \\
* * *\end{array}$ & $\begin{array}{l}0.160 \\
* * *\end{array}$ & $\begin{array}{l}0.097 \\
* * *\end{array}$ & $\begin{array}{l}0.023 \\
* * *\end{array}$ & $\begin{array}{l}0.040 \\
* * *\end{array}$ & $\begin{array}{l}-0.007 \\
* *\end{array}$ & $\begin{array}{l}-0.027 \\
* * *\end{array}$ & $\begin{array}{l}-0.056 \\
* * *\end{array}$ & $\begin{array}{l}0.255 \\
* * *\end{array}$ & $\begin{array}{l}0.140 \\
* * *\end{array}$ & $\begin{array}{l}0.098 \\
* * *\end{array}$ & $\begin{array}{l}0.067 \\
* * *\end{array}$ & 1 & & \\
\hline 25 & new firm & $\begin{array}{l}0.051 \\
* * *\end{array}$ & $\begin{array}{l}0.037 \\
* * *\end{array}$ & 0.048 & 0.003 & $\begin{array}{l}-0.004 \\
* * *\end{array}$ & $\begin{array}{l}0.024 \\
* * *\end{array}$ & 0.029 & 0.001 & $\begin{array}{l}-0.004 \\
* * *\end{array}$ & $\begin{array}{l}0.013 \\
* * *\end{array}$ & $\begin{array}{l}0.057 \\
* * *\end{array}$ & -0.001 & $\begin{array}{l}0.069 \\
* * *\end{array}$ & $\begin{array}{l}0.049 \\
* * *\end{array}$ & -0.004 & $\begin{array}{l}-0.011 \\
* * *\end{array}$ & $\begin{array}{l}0.208 \\
* * *\end{array}$ & $\begin{array}{l}-0.111 \\
* * *\end{array}$ & $\begin{array}{l}-0.097 \\
* * *\end{array}$ & $\begin{array}{l}0.065 \\
* * *\end{array}$ & $\begin{array}{l}-0.033 \\
* * *\end{array}$ & $\begin{array}{l}0.027 \\
* * *\end{array}$ & $\begin{array}{l}0.033 \\
* * *\end{array}$ & $\begin{array}{l}-0.038 \\
* * *\end{array}$ & & \\
\hline 26 & market share & 0.064 & $\begin{array}{l}-0.005 \\
* * *\end{array}$ & $\begin{array}{l}0.105 \\
* * *\end{array}$ & 0.002 & -0.004 & $\begin{array}{l}-0.019 \\
* *\end{array}$ & $\begin{array}{l}0.008 \\
* *\end{array}$ & 0.026 & -0.004 & $\begin{array}{l}0.005 \\
* * *\end{array}$ & $\begin{array}{l}0.098 \\
* * *\end{array}$ & $\begin{array}{l}0.034 \\
* * *\end{array}$ & $\begin{array}{l}0.075 \\
* * *\end{array}$ & $\begin{array}{l}0.067 \\
* * *\end{array}$ & $\begin{array}{l}0.029 \\
* * *\end{array}$ & -0.002 & $\begin{array}{l}-0.031 \\
* * *\end{array}$ & $\begin{array}{l}0.316 \\
* * *\end{array}$ & $\begin{array}{l}0.347 \\
* * *\end{array}$ & $\begin{array}{l}0.044 \\
* * *\end{array}$ & $\begin{array}{l}0.131 \\
* * *\end{array}$ & $\begin{array}{l}0.042 \\
* * *\end{array}$ & $\begin{array}{l}0.011 \\
* *\end{array}$ & $\begin{array}{l}0.058 \\
* * *\end{array}$ & $\begin{array}{l}-0.0121 \\
* * *\end{array}$ & \\
\hline
\end{tabular}


A3 - Estimation first-stage model (unbalanced panel)

\begin{tabular}{|c|c|c|c|c|c|c|c|c|c|}
\hline DV: Innovation & Year 2005 & Year 2006 & Year 2007 & Year 2008 & Year 2009 & Year 2010 & Year 2011 & Year 2012 & Year 2013 \\
\hline \multirow[t]{2}{*}{ Size } & 0.039 & 0.045 & $0.105^{*}$ & $0.186 * * *$ & $0.174 * * *$ & $0.181 * * *$ & $0.212 * * *$ & $0.261 * * *$ & $0.212 * * *$ \\
\hline & $(0.060)$ & $(0.056)$ & $(0.056)$ & $(0.055)$ & $(0.057)$ & $(0.057)$ & $(0.059)$ & $(0.060)$ & $(0.061)$ \\
\hline \multirow[t]{2}{*}{ Size 2} & -0.006 & -0.006 & $-0.011 *$ & $-0.015 * * *$ & $-0.011 *$ & $-0.011 *$ & $-0.010^{*}$ & $-0.015 * *$ & -0.009 \\
\hline & $(0.006)$ & $(0.006)$ & $(0.006)$ & $(0.006)$ & $(0.006)$ & $(0.006)$ & $(0.006)$ & $(0.006)$ & $(0.006)$ \\
\hline \multirow[t]{2}{*}{ Cost obstacles } & $0.339 * * *$ & $0.428 * * *$ & $0.490 * * *$ & $0.514 * * *$ & $0.480 * * *$ & $0.294 * * *$ & $0.282 * * *$ & $0.260 * * *$ & $0.267 * * *$ \\
\hline & $(0.065)$ & $(0.058)$ & $(0.059)$ & $(0.060)$ & $(0.060)$ & $(0.060)$ & $(0.061)$ & $(0.061)$ & $(0.062)$ \\
\hline \multirow[t]{2}{*}{ Market obstacles } & $0.517 * * *$ & $0.333 * * *$ & $0.230 * * *$ & $0.373 * * *$ & $0.324 * * *$ & $0.366^{* * *}$ & $0.387 * * *$ & $0.392 * * *$ & $0.489 * * *$ \\
\hline & $(0.068)$ & $(0.061)$ & $(0.061)$ & $(0.062)$ & $(0.062)$ & $(0.063)$ & $(0.064)$ & $(0.065)$ & $(0.068)$ \\
\hline \multirow[t]{2}{*}{ Knowledge obstacles } & $0.257 * * *$ & $0.393 * * *$ & $0.414 * * *$ & $0.412 * * *$ & $0.361 * * *$ & $0.542 * * *$ & $0.510 * * *$ & $0.521 * * *$ & $0.527 * * *$ \\
\hline & $(0.086)$ & $(0.078)$ & $(0.079)$ & $(0.078)$ & $(0.080)$ & $(0.081)$ & $(0.082)$ & $(0.084)$ & $(0.087)$ \\
\hline \multirow[t]{2}{*}{ Other obstacles } & $-1.266^{* * *}$ & $-1.308 * * *$ & $-1.260 * * *$ & $-1.263 * * *$ & $-1.324 * * *$ & $-1.402 * * *$ & $-1.305^{* * *}$ & $-1.442 * * *$ & $-1.410 * * *$ \\
\hline & $(0.059)$ & $(0.054)$ & $(0.055)$ & $(0.055)$ & $(0.057)$ & $(0.058)$ & $(0.059)$ & $(0.061)$ & $(0.064)$ \\
\hline \multirow[t]{2}{*}{ Market share } & $3.198 * * *$ & $4.658 * * *$ & $5.894 * * *$ & $10.176^{* * *}$ & $7.160 * * *$ & $6.387 * * *$ & $4.967 * * *$ & $5.095 * * *$ & $3.261 * * *$ \\
\hline & $(0.837)$ & $(1.000)$ & $(1.100)$ & $(1.224)$ & $(1.142)$ & $(1.070)$ & $(0.955)$ & $(0.982)$ & $(0.780)$ \\
\hline \multirow[t]{2}{*}{ Group } & $0.163 * * *$ & $0.100 * * *$ & $0.158 * * *$ & $0.178 * * *$ & $0.141 * * *$ & $0.160 * * *$ & $0.137 * * *$ & $0.118 * * *$ & $0.180 * * *$ \\
\hline & $(0.037)$ & $(0.035)$ & $(0.035)$ & $(0.034)$ & $(0.035)$ & $(0.035)$ & $(0.036)$ & $(0.037)$ & $(0.037)$ \\
\hline \multirow[t]{2}{*}{ Constant } & -0.248 & -0.212 & $-0.413 * * *$ & $-0.842 * * *$ & $-0.861 * * *$ & $-0.862 * * *$ & $-1.184 * * *$ & $-1.309 * * *$ & $-1.291 * * *$ \\
\hline & $(0.151)$ & $(0.137)$ & $(0.137)$ & $(0.137)$ & $(0.145)$ & $(0.145)$ & $(0.149)$ & $(0.153)$ & $(0.156)$ \\
\hline Obs. & 8028.00 & 9561.00 & 9277.00 & 9039.00 & 8561.00 & 8195.00 & 7822.00 & 7453.00 & 7093.00 \\
\hline $\log \mathrm{L}$ & -4166.32 & -4851.35 & -4924.12 & -4920.26 & -4727.58 & -4529.60 & -4459.17 & -4177.13 & -3961.70 \\
\hline Pseudo R2 & 0.21 & 0.21 & 0.19 & 0.19 & 0.18 & 0.19 & 0.17 & 0.19 & 0.19 \\
\hline
\end{tabular}




\section{References}

Aghion, P., \& Saint-Paul, G. (1998). 'Virtues of bad times. Interaction Between Productivity Growth and Economic Fluctuations', Macroeconomic Dynamics, 2/3: 322-44. Cambridge University Press.

Archibugi, D., Filippetti, A., \& Frenz, M. (2013a). 'The impact of the economic crisis on innovation: evidence from Europe', Technological Forecasting and Social Change, 80/7: 1247-60. Elsevier Inc. DOI: 10.1016/j.techfore.2013.05.005

- (2013b). 'Economic crisis and innovation: Is destruction prevailing over accumulation?', Research Policy, 42/2: 303-14. Elsevier B.V. DOI: 10.1016/j.respol.2012.07.002

Arranz, N., De Arroyabe, J. C. F., \& Arroyabe, J. de. (2008). 'The choice of partners in R\&D cooperation: An empirical analysis of Spanish firms', Technovation, 28/1-2: 88-100. DOI: 10.1016/j.technovation.2007.07.006

Arvanitis, S., \& Bolli, T. (2013). 'A Comparison of National and International Innovation Cooperation in Five European Countries', Review of Industrial Organization, 43/3: 163-91. DOI: 10.1007/s11151-012-9348-6

Badillo, E. R., \& Moreno, R. (2015). 'Does absorptive capacity determine collaborative research returns to innovation? A geographical dimension', The Annals of Regional Science. Springer Berlin Heidelberg. DOI: 10.1007/s00168-015-0696-7

Barge-Gil, A. (2010). 'Cooperation-based innovators and peripheral cooperators: An empirical analysis of their characteristics and behavior', Technovation, 30/3: 195206. DOI: 10.1016/j.technovation.2009.11.004

_ (2013). 'Open strategies and innovation performance', Industry and Innovation, 20/7: 585-610.

Barlevy, G. (2004). 'On the timing of innovation in stochastic Schumpeterian growth models', NBER working paper series working paper 10741.

Barrett, C., Musso, C., \& Padhi, A. (2009). 'Upgrading R\&D in a downturn', McKinsey Quarterly, February.

Becker, W., \& Dietz, J. (2004). 'R\&D cooperation and innovation activities of firms Evidence for the German manufacturing industry', Research Policy, 33/2: 209-23. DOI: 10.1016/j.respol.2003.07.003

van Beers, C., \& Zand, F. (2014). 'R\&D Cooperation, Partner Diversity, and Innovation Performance: An Empirical Analysis', Journal of Product Innovation Management, 31/2: 292-312. DOI: 10.1111/jpim.12096

Belderbos, R., Carree, M., \& Lokshin, B. (2004). 'Cooperative R\&D and firm performance', Research Policy, 33/10: 1477-92. DOI: 10.1016/j.respol.2004.07.003

Belderbos, R., Carree, M., Lokshin, B., Sastre, J. F., \& Fernández Sastre, J. (2015). 'Inter-temporal patterns of R\&D collaboration and innovative performance', The Journal of Technology Transfer, 40/1: 123-37. DOI: 10.1007/s10961-014-9332-4

Berchicci, L., Jong, J. P. J. de, \& Freel, M. (2015). 'Remote collaboration and innovative performance: the moderating role of R\&D intensity', Industrial and Corporate Change. DOI: 10.1093/icc/dtv031

Cantwell, J. A. (1989). Technological Innovation and Multinational Corporations. Oxford: Blackwell.

Cassiman, B., \& Veugelers, R. (2006). 'In Search of Complementarity in Innovation Strategy: Internal R\&D and External Knowledge Acquisition', Management Science, 52/1: 68-82. DOI: 10.1287/mnsc.1050.0470 
Chesbrough, H. W. (2003). Open Innovation: The New Imperative for Creating and Profiting from Technology. Boston: Harvard Business School Press.

Chesbrough, H. W., \& Garman, A. R. (2009). 'Use open innovation to cope in a downturn', Harvard Business Review, 87/October: 1-10.

Cincera, M., Cozza, C., Tübke, A., \& Voigt, P. (2012). 'Doing R\&D or not (in a crisis), that is the question...', European Planning Studies, 20/9: 1525-47. DOI: 10.1080/09654313.2012.709064

Cohen, W. M., \& Levinthal, D. A. (1990). 'Absorptive Capacity: A New Perspective on Learning and Innovation', Administrative Science Quarterly, 35/1: 128-52. Johnson Graduate School of Management, Cornell University.

Cruz-Castro, L., \& Sanz-Menéndez, L. (2015). 'The effects of the economic crisis on public research: Spanish budgetary policies and research organizations', Technological Forecasting and Social Change, forthcomin/April 2012: 139-40. Elsevier Inc. DOI: http://dx.doi.org/10.1016/j.techfore.2015.08.001

D'Este, P., Amara, N., \& Olmos-Peñuela, J. (2015). 'Fostering novelty while reducing failure: Balancing the twin challenges of product innovation', Technological Forecasting and Social Change, forthcomin.

Duysters, G., \& Lokshin, B. (2011). 'Determinants of Alliance Portfolio Complexity and Its Effect on Innovative Performance of Companies', Journal of Product Innovation Management, 28/4: 570-85. DOI: 10.1111/j.1540-5885.2011.00824.x

European Commission. (2015). European Economic Forecast. Autumn 2015. Luxembourg: European Union. DOI: 10.2765/030941

Filippetti, A., \& Archibugi, D. (2011). 'Innovation in times of crisis: National Systems of Innovation, structure, and demand', Research Policy, 40/2: 179-92. DOI: 10.1016/j.respol.2010.09.001

Frenz, M., \& Ietto-Gillies, G. (2009). 'The impact on innovation performance of different sources of knowledge: Evidence from the UK Community Innovation Survey', Research Policy, 38/7: 1125-35.

Geroski, P., \& Walters, C. (1995). 'Innovative Activity over the Business Cycle', The Economic Journal, 105/431: 916-28. DOI: 10.2307/2235158

Hud, M., \& Hussinger, K. (2015). 'The impact of R\&D subsidies during the crisis', Research Policy, 44/10: 1844-55. Elsevier B.V. DOI: 10.1016/j.respol.2015.06.003

Hung, K.-P., \& Chou, C. (2013). 'The impact of open innovation on firm performance: The moderating effects of internal $\mathrm{R} \& \mathrm{D}$ and environmental turbulence', Technovation, 33/10-11: 368-80. Elsevier. DOI: 10.1016/j.technovation.2013.06.006

Keeley, B., \& Love, P. (2010). OECD Insights: From Crisis to Recovery. The Causes, Course and Consequences of the Great Recession. Paris. DOI: 10.1787/9789264077072-en

Kogut, B., \& Zander, U. (1992). 'Knowledge of the Firm, Combinative Capabilities, and the Replication of Technology', Organization Science, 3/3: 383-97. DOI: 10.1287/orsc.3.3.383

Koza, M. P., \& Lewin, A. Y. (1998). 'The Co-Evolution of Strategic Alliances', Organization Science, 9/3: 255-64. INFORMS. DOI: 10.1287/orsc.9.3.255

Laperche, B., Lefebvre, G., \& Langlet, D. (2011). 'Innovation strategies of industrial groups in the global crisis: Rationalization and new paths', Technological Forecasting and Social Change, 78: 1319-1331.

Laursen, K., \& Salter, A. (2006). 'Open for Innovation: The role of openness in 
explaining innovation performance among UK manufacturing firms', Strategic Management Journal, 27/2: 131-50. DOI: 10.1002/smj.507

Lavie, D., \& Miller, S. R. (2008). 'Alliance portfolio internationalization and firm performance', Organization Science, 19/4: 623-46. DOI: 10.1287/orsc.1070.0341

Lavie, D., \& Rosenkopf, L. (2006). 'Balancing exploration and exploitation in alliance formation', Academy of Management Journal, 49/4: 797-818.

Levinthal, D. A., \& March, J. G. (1993). 'The myopia of learning', Strategic Management Journal, 14/S2: 95-112. DOI: 10.1002/smj.4250141009

Lundvall, B.-Å. (1992). National systems of innovation: towards a theory of innovation and interactive learning. London: Pinter.

Madrid-Guijarro, A., García-Pérez-de-Lema, D., \& Van Auken, H. (2013). 'An investigation of Spanish SME innovation during different economic conditions', Journal of Small Business Management, 51/4: 578-601. DOI: 10.1111/jsbm.12004

March, J. G. (1991). 'Exploration and exploitation in organizational learning', Organization Science, 2/1: 71-87. DOI: 10.1287/orsc.2.1.71

Miotti, L., \& Sachwald, F. (2003). 'Co-operative R\&D: why and with whom?', Research Policy, 32/8: 1481-99. DOI: 10.1016/S0048-7333(02)00159-2

Mundlak, Y. (1978). 'On the pooling of time series and cross section data', Econometrica: journal of the Econometric Society.

Nieto, M. J., \& Santamaría, L. (2007). 'The importance of diverse collaborative networks for the novelty of product innovation', Technovation, 27/6-7: 367-77. DOI: 10.1016/j.technovation.2006.10.001

— (2010). 'Technological Collaboration: Bridging the Innovation Gap between Small and Large Firms', Journal of Small Business Management, 48/1: 44-69. DOI: $10.1111 / \mathrm{j} .1540-627 X .2009 .00286 . \mathrm{x}$

Nijman, T., \& Verbeek, M. (1992). 'Nonresponse in panel data: The impact on estimates of a life cycle consumption function', Journal of Applied Econometrics, 7/3: 243-57.

OECD. (2005). Oslo manual, guidelines for collecting and interpreting innovation. Paris: OECD.

- (2009). Policy responses to the economic crisis: investing in innovation. Paris: OECD.

Paunov, C. (2012). 'The global crisis and firms' investments in innovation', Research Policy, 41/1: 24-35. DOI: 10.1016/j.respol.2011.07.007

Porter, M. E. (1990). The Competitive Advantage of the Nations. New York: Free Press.

Posen, H., \& Levinthal, D. (2012). 'Chasing a moving target: Exploitation and exploration in dynamic environments', Management Science, 58/3: 587-601.

Raymond, W., Mohnen, P., Palm, F., \& van der Loeff, S. S. (2010). 'Persistence of innovation in Dutch manufacturing: is it spurious?', The Review of Economics and Statistics, 92/3: 495-504. DOI: 10.1162/REST_a_00004

Robin, S., \& Schubert, T. (2013). 'Cooperation with public research institutions and success in innovation: Evidence from France and Germany', Research Policy, 42/1: 149-66.

Rosenkopf, L., \& Nerkar, A. (2001). 'Beyond local search: Boundary-spanning, exploration, and impact in the optical disk industry', Strategic Management Journal, 22/4: 287-306. DOI: 10.1002/smj.160

Rothaermel, F., \& Deeds, D. (2006). 'Alliance type, alliance experience and alliance management capability in high-technology ventures', Journal of business venturing, 21/4: 429-60. 
Sampson, R. (2005). 'Experience effects and collaborative returns in R\&D alliances', Strategic Management Journal, 26/11: 1009-1031.

Schumpeter, J. A. (1939). Business Cycles: A Theoretical, Historical, and Statistical Analysis of the Capitalist Process. New York: New McGraw-Hill.

Schwartz, M., Peglow, F., Fritsch, M., \& Günther, J. (2012). 'What drives innovation output from subsidized R\&D cooperation?-Project-level evidence from Germany', Technovation, 32/6: 358-69. DOI: 10.1016/j.technovation.2012.03.004

Stiglitz, J. E. (1993). 'Endogenous Growth and Cycles', (No. w4286). National Bureau of Economic Research.

Tether, B. S. (2002). 'Who co-operates for innovation, and why: An empirical analysis', Research Policy, 31/6: 947-67.

Vega-Jurado, J., Gutiérrez-Gracia, A., \& Fernández-De-Lucio, I. (2009). 'Does external knowledge sourcing matter for innovation? Evidence from the Spanish manufacturing industry', Industrial and Corporate Change, 18/4: 637-70. DOI: 10.1093/icc/dtp023

Veugelers, R., \& Cassiman, B. (1999). 'Make and buy in innovation strategies: evidence from Belgian manufacturing firms', Research policy, 28/1: 63-80.

Wooldridge, J. M. (1995). 'Selection corrections for panel data models under conditional mean independence assumptions', Journal of Econometrics, 68: 11532. DOI: 10.1016/0304-4076(94)01645-G

- (2010). Econometric Analysis of Cross Section and Panel Data., 2nd ed. Cambridge, Mass. and London, UK: The MIT Press.

Zabel, J. (1992). 'Estimating fixed and random effects models with selectivity', Economics Letters, 40/3: 269-72.

Zeng, S. X., Xie, X. M., \& Tam, C. M. (2010). 'Relationship between cooperation networks and innovation performance of SMEs', Technovation, 30/3: 181-94. DOI: 10.1016/j.technovation.2009.08.003

\footnotetext{
${ }^{1}$ Some external innovation projects could regard new technologies and products, which is a truly explorative strategy. Other innovation alliances have the aim to improve existing products and processes, which have some elements of an exploitative behaviour. However, in the latter case, the firm is using external resources rather than internal, thus searching outside its boundaries something new, something that it does not know how to do internally. By using external partners, the firm is taking additional risks and uncertainty that make cooperation in innovation activities more explorative than exploitative.

2 This database is available at http://icono.fecyt.es/PITEC

${ }^{3}$ Possible issues reported are: firms belonging to a sector with high employment turnover; acquired firm; change in the unit of reference; change or abandonment of activity; firm remaining of an acquisition process (not part of the acquisition); in liquidation; merged; firm which has employees ceded by other firms; consequence of the crisis; firm which cedes employees to other firms.

${ }^{4}$ The sample size in 2004 is lower than 2005 and subsequent years. Hence, imposing the restriction of the balanced panel to firms present in 2004-2013 would have left out new firms entering in 2005 and staying for the remaining years.

5 These activities include: internal R\&D; external R\&D, acquisition of machinery, equipment and software; acquisition of other external knowledge; training; market introduction of innovations; other preparations.
} 
${ }^{6}$ We assume that the conditional mean of the individual effects are a linear projection on the within individual means of the timevariant regressors (Mundlak 1978; Nijman \& Verbeek 1992; Wooldridge 1995; Zabel 1992).

7 The specific question in the questionnaire is as follows (example for the 2013 edition): "In the period 2011-2013, did your enterprise cooperate in any of its innovation activities with other enterprises or institutions?"

8 This cooperation does not require that the parts achieve a commercial benefit and it excludes subcontracting without active cooperation.

${ }^{9}$ Note that these firms may also have national or international cooperation with same-group firms.

${ }^{10}$ For the geographical dimension, we do not distinguish between collaboration with firms in the same group or not from the same group, since we are interested in the capacity of the firm to undertake relations at different geographical levels. Hence, if they have collaboration agreements with foreign units of the same corporate company, but not exclusively, the firms are exposed to the same benefits as from an external partner located abroad. A different approach has been followed for the organizational dimension. The cooperation with the same-group firms and the one with partners that are external to the corporate group implies very different coordination mechanisms, hence they cannot be placed on the same level. Indeed, in the case of cooperation with a firm in the same group, the coordination occurs under the same company, with perhaps the upper hierarchical levels orchestrating the cooperation and mediating possible conflicts. On the contrary, in the case of cooperation with external partners, the coordination is between separated legal entities that need to clarify all the terms of their cooperation to avoid opportunistic behaviour. Therefore, the cases when firms cooperate with a single type of national external partners and with firms in the same group at the national level only are not considered a multi-partnership cooperation, and they have been included in the categories national only+vertical only, national only+horizontal only, or national only+institutional only. Similarly, the cases in which firms cooperate with a single type of national external partners and with firms in the same group in foreign countries cannot be considered a case of multi-partnership, neither exclusively nationally nor internationally, and they have been included in the corresponding categories of national only+vertical only, national only+horizontal or national only+institutional only.

11 An established literature following Laursen and Salter (2006) has used 'breadth' and 'depth' knowledge search variables in CIS data, built on the question (example in the questionnaire for 2013): "During the three years 2011 to 2013 , how important to your enterprise's innovation activities were each of the following information sources?'. Such sources include both formal and informal (e.g. knowledge coming from publications or regulations) access to external sources of knowledge. Instead, the variable cooperation allows us to focus only on formal cooperation, hence making the assumption that the access to external knowledge is part of a chosen exploration strategy, rather than the result of the availability of partially-public knowledge in the external environment. In addition, although it could be interesting to study whether exploration during turbulent times can involve 'breadth and depth' of knowledge search as used in Laursen and Salter (2006), our focus on the type of cooperation partners in terms of national/international and vertical/horizontal/institutional has the advantage of qualifying which type of source could be more relevant during the crisis, thus offering more straightforward policy and managerial implications to be used under economic crises.

12 These time frames reflect the pre- and during-crisis periods considered in the estimations, as discussed in Section 3.2.

13 To keep overlapping years to the lowest, we do not consider 2009. 